IZA DP No. 6033

Educational Scores: How Does Russia Fare?

Chiara Amini

Simon Commander

October 2011

Forschungsinstitut zur Zukunft der Arbeit Institute for the Study of Labor 


\title{
Educational Scores: How Does Russia Fare?
}

\author{
Chiara Amini \\ University College London
}

Simon Commander

IE Business School, EBRD,

Altura Advisers and IZA

\section{Discussion Paper No. 6033 \\ October 2011}

\author{
IZA \\ P.O. Box 7240 \\ 53072 Bonn \\ Germany \\ Phone: +49-228-3894-0 \\ Fax: +49-228-3894-180 \\ E-mail: iza@iza.org
}

\begin{abstract}
Any opinions expressed here are those of the author(s) and not those of IZA. Research published in this series may include views on policy, but the institute itself takes no institutional policy positions.

The Institute for the Study of Labor (IZA) in Bonn is a local and virtual international research center and a place of communication between science, politics and business. IZA is an independent nonprofit organization supported by Deutsche Post Foundation. The center is associated with the University of Bonn and offers a stimulating research environment through its international network, workshops and conferences, data service, project support, research visits and doctoral program. IZA engages in (i) original and internationally competitive research in all fields of labor economics, (ii) development of policy concepts, and (iii) dissemination of research results and concepts to the interested public.
\end{abstract}

IZA Discussion Papers often represent preliminary work and are circulated to encourage discussion. Citation of such a paper should account for its provisional character. A revised version may be available directly from the author. 
IZA Discussion Paper No. 6033

October 2011

\section{ABSTRACT \\ Educational Scores: How Does Russia Fare?*}

This paper uses two large multi-country datasets on educational scores - PISA and TIMSS to examine the performance of Russia in comparative light as well as the factors associated with differences in educational outcomes in Russia. Despite the perception of a positive educational legacy, Russian scores are not stellar and have mostly deteriorated. Using an education production function, we distinguish between individual and family background factors and those relating to the school and institutional environment. We use pooled data, as well as cross sectional evidence, to look at the variation across countries before looking at within-country variation in Russia. We find - both in the cross-country estimates as also those using just Russia data - that a number of individual and family variables in particular, such as parental educational levels, are robustly associated with better educational outcomes. Institutional variables also matter - notably student-teacher ratios and indicators of school autonomy - but there are also some clear particularities in the Russian case.

JEL Classification: $\quad H 5,121,128, \mathrm{~J} 24, \mathrm{O} 15, \mathrm{P} 5$

Keywords: $\quad$ human capital, PISA

Corresponding author:

Simon Commander

EBRD

One Exchange Square

London EC2A 2JN

United Kingdom

E-mail: commanders@ebrd.com

\footnotetext{
* We thank Erik Berglof, Irina Denisova, Janos Kollo, Steve Machin, Zlatko Nikoloski, Alexander Plekhanov, Natalya Volchkova and Katya Zhuravskaya for helpful comments and discussion.
} 


\section{Introduction}

A substantial body of research now exists that examines the impact of different measures of educational outcomes on both individual and economy-wide performance. This work has reflected a shift away from measures of educational inputs, such as years of schooling, to those that attempt to capture the value of the education that has been imparted. Hanushek and Woessman (2007, 2009, 2010), for example, have argued that differences in the quality of education matter more in explaining cross-country differences in productivity growth than differences in the average number of years of schooling or enrolment rates.

Our paper extends this emphasis to look in detail at the quality of the education in a country - Russia - that as a previously planned economy was widely assumed to have generated better human capital than economies at broadly comparable levels of income. Although subsequent research has rather qualified this assumption - at least in the context of other transition economies ${ }^{2}$ - little analysis has yet been done using individual educational scores, let alone in a way that allows cross-country and within-country comparison.

Transition has involved large and persistent shocks to physical capital stocks and, in some instances, large shifts in the composition of output. This has had implications for human capital, both through a shift in demand for particular skills as well as through the direct effect of resource allocations to education spending. In Russia, two significant processes have been at work. The first has involved the destruction or contraction of broad based manufacturing and the growing preponderance of natural resources in the structure of output and trade. One expectation could be that as the productive base of the economy has narrowed so will have the underlying skills or capability set. This narrowing might in turn have limited the ability to induce any further diversification of the economy.

The second has been the impact of policy in the education sector, where a series of attempts at institutional change have been put in place. There have also been significant annual fluctuations in the volume of resources allocated by government to education. Indicatively, in the early 1970 s roughly $7 \%$ of GDP was allocated to education. By the early 1990s this had fallen to around 3.5\%, approaching 4\% by 2006/7. In 1992 a new

\footnotetext{
${ }^{2}$ See, for example, Munich et al (2005), Brunello et al (2011).
} 
law mandated that spending on education should not fall below $10 \%$ of the federal budget. In the last decade, this threshold has been reached or exceeded.

Our paper uses two sets of international achievement scores - PISA and TIMMS to examine differences in scores across a large group of countries sampled in these datasets, including Russia. It then tries to explain the variation in scores within Russia. By using both datasets, we are able to cover not only a range of disciplines from reading to mathematics and science but also to introduce a comparative element into the analysis.

Needless to say, there are important caveats when using large multi-country datasets like PISA and TIMSS. Countries have very different educational systems - Russia and its Soviet legacy is a clear case in point - and there is a large set of possible country attributes that could be used to explain differences across countries ${ }^{3}$. Further, while these scores can be helpful in seeing how students perform in standardised tests in key disciplines, they are not necessarily very informative about the actual skills being acquired by those students, and hence their labour market prospects. Evidence from other transition countries that has looked explicitly at the relation between education and skills has found a surprisingly weak association. This has led employers to make hiring decisions based on attributes - such as age - rather than on reported educational attainment or degrees ${ }^{4}$. This apparent decoupling obviously raises some important questions as to the possible policy conclusions that can be drawn.

As regards the measurement of educational attainment, TIMSS explicitly measures achievements relative to the curriculum, much of which in Russia remains only partially reformed. TIMSS is focussed on mathematics and science. By contrast, in PISA there is an explicit attempt to measure abilities that are needed to function in a modern economy and the instrument is hence explicitly dissociated from the formal curriculum. As well as mathematics and science, PISA also measures reading abilities. Using both datasets, despite their different methodologies provides the widest possible angle on how students, Russians in particular, perform across different disciplines as well as across time. In the text, we report results from the PISA dataset, presenting complementary results from the analysis of TIMSS mostly in appendices.

\footnotetext{
${ }^{3}$ A point made by Freeman et al (2010) who further note that cross-country studies will not give as robust conclusions about educational processes as random assignment studies or analysis based on particular inputs.

${ }^{4}$ See, for instance, Kollo (2007)
} 
Our approach involves estimating education production functions that relate educational outcomes to characteristics in order to identify the relative impact of student, parent and school variables. For both PISA and TIMSS we pool the data over multiple rounds. In the pooled regressions with multiple country observations, we are able to pick out country-specific effects. We also offer alternative specifications that take account of the multilevel nature of the data.

\section{Russian Education in context}

The Russian education system, despite many changes, is still coloured by the legacy of the previous system and the incomplete reforms started since 1991. The Soviet system certainly achieved very strong enrolment results. These have subsequently declined. Between 2003 and 2008 alone gross enrolment rates for secondary education fell from 93 to 85 and for primary education from 117 to 97.

The legacy also included a highly centralised system of control - including of curricula, personnel, management as well as financing. A feature of the changes introduced since 1991 has been the greater devolution of authority by the federal government to lower levels. This has not necessarily been positive. Financial constraints have been significant but have also varied widely across jurisdictions. There has been a creeping de facto privatisation of education. Schools and teachers have commonly imposed fees and levies, while some schools have also launched revenue-earning schemes of a non-educational nature. Some explicitly private institutions have also been established.

The shift to greater decentralisation has been accompanied by great heterogeneity in spending and decision-making across regions and municipalities. For example, in 2001 over 35\% of oblasts or regions spent between 500-1000 roubles per student, while just over $10 \%$ of regions spent over 1500 . There has also been the emergence of special institutions, such as gymnasia, lycees, colleges, outside the basic public system.

While there is considerable debate about the appropriate policies to be pursued, there is relatively broad agreement that Russian education has only weakly focussed on educational outcomes, giving priority instead to standardised measures of inputs. These in turn have been compromised by varying budgetary means across regions. Antiquated curricula, low standards of pedagogy and management have been highlighted. This has led some to promote policies designed to achieve new standards, the overhaul of 
curricula and teaching methods, more and better assessment of students and greater emphasis on learning outcomes, as well as more autonomy for schools ${ }^{5}$.

Institutionally, the system has maintained a requirement for 10 years of compulsory education. Entry to primary school begins at 7 years, lower secondary at 10/11 years and upper secondary at 15/16 years. As such, basic general education lasts for 9 years. At that point, students can pursue higher secondary or enter a vocational school. The $8^{\text {th }}$ grade or 15 year reference for the PISA and TIMSS datasets that we use in this paper thus captures students at the end of their lower secondary phase.

\section{Data}

We use two complementary data sources - the OECD's Programme for International Student Assessment (PISA) and the International Association for the Evaluation of Educational Achievement's Trends in International Mathematics and Science Study (TIMSS). Both databases have been quite widely used and described. PISA is an international, standardised assessment of 15-year-old students' performance in mathematics, science, and reading. It has been administered in all OECD countries as well as a growing number of non-OECD countries, of which Russia has been one. To date, 4 rounds have been collected in 2000, 2003, 2006 and 2009. 35 countries, including Russia, have been included in each round. For each country, students have been randomly sampled within schools ${ }^{6}$. Students have been given a reading, mathematics and science literacy test. In addition, information on the students - such as family background, attitudes towards schooling and learning strategies - has been collected. Further, each round of PISA has collected information from school principals on school resources, such as the number of teachers in the school. This provides multi-level information on students, their family environment and the schools they attend.

TIMSS consists of international tests of mathematics and science for both $4^{\text {th }}$ and $8^{\text {th }}$ grade students. In this paper we use the information for the $8^{\text {th }}$ grade equivalent to 15 years of age and hence comparable to PISA. For TIMSS, schools in each country that have classes at $4^{\text {th }}$ and $8^{\text {th }}$ grades are sampled with classes within schools and students within classes sampled to achieve representativeness. TIMSS has now been implemented in 1995, 1999, 2003 and 2007. In 1995 and 199740 countries were surveyed, rising to 59 by 2007 . Russia and 14 other countries, including the USA, England, Italy, Japan and

\footnotetext{
${ }^{5}$ See, for example, Canning (2004)

${ }^{6}$ See description in Anderson et al (2010). The primary sampling unit has been the school.
} 
Korea, have been present in each of the four rounds. Unlike PISA which is disconnected from national curricula and aims to measure skills required to function in a modern economy, TIMSS aims to align its tests with the curricula taught in each of the surveyed countries. However, given that our interest is primarily in understanding whether Russian human capital is fit for purpose in a modern economy, the PISA approach has some advantage and hence priority in the text is given to presenting results from analysis of the PISA data.

Both PISA and TIMSS have a broad coverage of students and apply a substantial number of questions by dividing tests into sub-clusters. In this design, each student responds to a fraction of the entire assessment ${ }^{7}$. Testing students only on a subset of questions could lead to substantial measurement error if the aim of the test is to measure students' ability to answer all questions. Plausible values are a sample of scores from the distribution of a student's scores as if the student had responded to all questions in the test. Plausible values are based on student responses to the subset of items they receive conditional on the background characteristics ${ }^{8}$. In PISA, these individual test scores are standardized in a subsequent step so that the unconditional sample mean of each round equals 500 and their unconditional sample standard error equals 100. TIMSS similarly standardises the average score across countries to 500 with a standard deviation of 100 .

\subsection{Descriptive statistics}

Figures 1-3 provide the PISA scores for Reading, Mathematics and Science for a subset of countries, including Russia, that have been present in all rounds (viz., 2000, 2003, 2006 and 2009). For mathematics, Russia scores consistently higher than Brazil - and indeed other emerging markets covered by PISA. Its score is roughly comparable to that of the USA in all rounds, but notably lower than Asian countries, such as Japan or Korea, as well as the leading European countries, like Finland. The ratio of the top countries Korea and Hong Kong - to Russia in 2009 was around 1.18. At the start of the period, Russia ranked $25^{\text {th }}$ out of 35 countries for mathematics and this was stable through to $2009^{9}$. For both reading and science, Russian scores tend to be weaker relative to most of Europe, including other transition countries, as well as to Asia, although they still remain superior to emerging markets, such as Brazil. The ratio of the top countries to Russia was

\footnotetext{
${ }^{7}$ Willms and Smith (2005)

${ }^{8}$ Mislevy (1991)

${ }^{9}$ This compares to countries included in all rounds. By 2009 the total number of countries in the PISA sample had risen to 57.
} 
1.17 and 1.14 respectively. For reading and science, Russia ranked $29 / 30^{\text {th }}$ out of 35 at the start and end periods. By 2009 Russia's mean reading score was statistically significantly lower than the OECD average, being roughly equivalent to Chile and Turkey.

Figures 4-5 repeats the same exercise for TIMSS. With this measure, Russia performs significantly better in both mathematics and science than in PISA. In the case of mathematics, Russian scores are slightly superior to the USA or England, as well as many European, including other transition, countries. They are significantly higher than other emerging markets in the sample, but lower than the leading Asian countries, such as Taipei, Japan or Korea. For science, Russian scores are also relatively high. The ratio of the top countries' mean scores to Russia in 2007 was 1.15 in mathematics and 1.04 in science.

With respect to dispersion in scores, the percentile ratio of the $\left(90^{\text {th }} / 10^{\text {th }}\right) / 10^{\text {th }}$ for each of the three disciplines ranges in PISA between 0.51-0.54 and is larger than the mean for the full sample (0.48-0.5) as well as for most countries in Western Europe, although quite comparable to the USA. In the TIMSS date, dispersion in Russia for both mathematics and science is below the mean for the sample, comparable to the European countries and significantly lower than for other emerging markets. More generally, Freeman et al (2010) note that in the TIMSS, lower inequality in test scores tends to be associated with higher average scores.

Country average scores suggest several initial conclusions. The first is that there are clear and significant differences in how Russia has scored depending on the instrument. The TIMSS scores give consistently higher outcomes in mathematics and science. This difference may reflect the different survey strategies that have been pursued. In PISA, in particular, although Russia has performed better than most other emerging markets, it has under-performed relative to the main body of OECD countries. The reading score has been particularly weak. Second, with the exception of the TIMSS science score, there has been no improvement in Russian scores since the mid-1990s.

Given the policy objectives of diversifying the economy and raising productivity, a further facet is also troubling. Figures 6 provide evidence from PISA concerning the upper part of the scores distribution. This indicator may be particularly relevant when considering the ability of an economy to innovate. It shows that by 2009 the share of top performers - defined as those attaining Level 5 or above - in reading, mathematics and science ranged between 10-5\%, compared with $13-25 \%$ for the leading countries. In 
mathematics, for example, the top share in 2009 was around 6\% in Russia compared to 20-25 for Japan, Korea and Finland. Further, the top share had fallen sharply from around $10 \%$ in 2000 . There has been no improvement in the reading share while that for sciences betrays no clear trend. In sum, Russia has a relatively low share of top performers that has declined in the case of mathematics and registered little or no improvement in the other disciplines over the past decade. In TIMSS the share in the top $10 \%$ of the distribution for mathematics and science was $11 \%$ and $14 \%$ respectively ${ }^{10}$. This again contrasts unfavourably with the leading countries, Japan and Korea, with shares of $20-37 \%$, although is relatively high when compared with either Western Europe or North America.

Other research has signalled the fact that there are non-trivial differences in scores across gender. As in Machin and Pekkarinen (2008), we use three indicators: the gender gap, the variance ratio and the ratio male to female top performers ${ }^{11}$. In general for both PISA and TIMMS, the gender gap favours boys in mathematics and girls in reading while the picture for science is mixed. The variance ratio and the ratio of male to female top performers also show that boys' scores have greater variability compared to girls and that boys dominate in terms of top performers in mathematics and girls in reading. However, for Russia any advantage of boys over girls is smaller when compared to other countries. Figure 6 shows the gender gap in math and reading, calculated using PISA data from 2000 to 2009, for a selected number of countries. In Russia the gender gap for math is 0.06. This is well below the gender gap for the all sample, 0.13 , and also lower than for other emerging economies, such as Brazil and Mexico with values of 0.26 and 0.2 , respectively. The gender gap for reading in Russia is -0.39 which is slightly higher than for the whole sample (-0.36) and considerably higher then Brazil (-0.28) or Mexico, (0.26). The ratio of male to female top performers in mathematics is also lower than for other emerging markets.

\section{Determinants of Educational Performance}

\subsection{Estimation Strategy}

We adopt an educational production function approach. Such a function can most

\footnotetext{
${ }^{10}$ We do not have a comparable (Level 5 and above) measure for TIMSS so use the top 10\% instead.

11 The gender gap is the standardized mean difference in scores at mean value. The variance ratio is defined as the ratio of male to female variance. The ratio of male to female top performers is the ratio of the number of boys to the number of girls that have attained level 5 or above.
} 
generally be described by;

$\mathrm{F}(\mathrm{y}, \mathrm{x}) \leq \mathrm{C}$

where $y$ is a vector of educational outcomes and $x$ is a vector of inputs. $C$ is a positive scalar and $F$ represents the educational technology that transforms $x$ into $y$. Inputs comprise a set of school related factors such as class size, student-teacher ratios, measures of teacher quality and experience. Educational outcomes represent the cognitive development of the student as given by standardised test scores or examination results. If an educational technology changes, the production possibilities frontier can either shift inwards or outwards as $F$ is a strictly quasi-concave, twice differentiable function which forms a convex production set. Educational production functions can be estimated empirically. Frontier estimation aimed at evaluating the performance of schools in relation to the production frontier can be either parametric or non-parametric. This approach would be particularly relevant when the aim is to identify those schools which have the best possible outcomes for a given level of inputs. An alternative approach, which we rely on in this paper, is to estimate the educational production function using parametric methods in order to examine whether higher resource levels are associated with better outcomes, when controlling for attributes, both individual and family as well as institutional ${ }^{12}$.

Despite being widely used in helping design policy ${ }^{13}$, education production functions have obvious shortcomings. Aside from the matter of getting good, comparable measures of outcomes, they may be poor tools for measuring the complex classroom processes that underpin learning ${ }^{14}$. Further, modeling outcomes without allowing for the hierarchical nature of the data - such as clusters of students in classrooms, classes within schools and schools within educational management systems may be problematic ${ }^{15}$. However, the most common critique concerns the potential endogeneity of educational outcomes. For example, parents may be able to select better schools. As such if the link between socio-economic characteristics and funding is not fully controlled for, a model of educational attainment may generate a spurious negative

\footnotetext{
${ }^{12}$ For example, see Mayston and Jesson (1999).

${ }^{13}$ See Kann and Kiefer (2007)

${ }^{14}$ Goldhaber and Brewer (1997).

${ }^{15}$ See Goldstein (1987), (1995).
} 
correlation between school resources and achievement ${ }^{16}$. One way of addressing issues of endogeneity is to estimate a model that controls for the pupil's initial ability and socioeconomic background as well as other variables, such as gender and ethnicity. Information on parents' origin, education and the number of books at home ${ }^{17}$, variables that will not, or are unlikely to, change over time can serve as a proxy for prior inputs, allowing a causal relationship to be imputed ${ }^{18}$.

Aside from family background variables, we could also expect there to be other factors that affect the educational performance of individuals and which may be considered as inputs into the production of education. These include teaching and administrative inputs as well as other institutional factors. The type of relevant variables include, teacher-pupil ratios, measures of teaching experience (such as years), teacher education, library size, number of computers, audio-visual equipment, number and quality of laboratories as well as information on the ownership of the school ${ }^{19}$. Interestingly, existing research has found a weak or absent systematic relationship between school expenditures and student performance, particularly in developing and emerging markets ${ }^{20}$. Moreover, there may be measurement issues as commonly used variables — such as teacher experience or education - may not be closely correlated with actual ability in the classroom. Similarly, although there is some evidence that students tend to perform better in schools that have autonomy in personnel and day-to-day decisions, measures of autonomy are hard to implement as it is generally a decision for a country (or state) as a whole, leaving no comparison group within countries ${ }^{21}$.

In sum, the educational performance of individuals is likely to be affected by several types of inputs ranging from family background to teaching and administrative inputs as well as institutional factors.

\subsection{Implementation}

We pool the PISA data for four rounds (viz., 2000, 2003, 2006 and 2009). We include only individual observations from 35 countries that have been included in all rounds, which yield over 405,000 observations. For TIMSS, we pool the data from the first two

\footnotetext{
${ }^{16}$ See Vignoles et al (2000) where there is a wider discussion of the theoretical and empirical strengths and shortcomings of this approach.

${ }^{17}$ See Cooper and Chon (1997), Gyimah-Brempong and Gyapong (1991)

18 Ammermueller (2007)

${ }^{19}$ See the discussion in Cooper and Chon (1997)

${ }^{20}$ See Banerjee et al (2007); Duflo et al (2009), Hanushek and Woesmann (2010)

${ }^{21}$ See Hanushek and Woesmann (2007), (2010)
} 
rounds (1995 and 1997) as well as from the later rounds (2003 and 2007) yielding nearly 157,000 and over 237,000 observations respectively. This separation is because the survey instrument changed significantly between 1997 and 2003 rounds, thereby limiting comparability. Year and country dummies are included in all estimates ${ }^{22}$. To ensure that pooling is appropriate, we implemented a Chow test to see whether the coefficients from the pooled estimation were significantly different from those done on the cross sections. A cumulative test on all the coefficients of the variables that we have used shows that is appropriate to pool $^{23}$.

We estimate initially by ordinary least squares (OLS),

$$
E S_{i c s}=\alpha+\beta X_{i c s}+\gamma Y_{i c s}+\delta Z_{i c s}+\lambda C+\chi T+\varepsilon_{i c s}
$$

where $E S=$ educational score for mathematics, science or reading, $X$ is a vector of individual characteristics, $Y$ is a vector of family attributes, $Z$ is a vector of schoolspecific features, while $C$ and $T$ signify country and year controls. The $E S$ variables are the individual test scores for each discipline registered in either PISA or TIMSS by each student. For the PISA estimates, the vector, $X$, contains a combination of an individual's age, gender, where born and language spoken at home. Family attributes, $Y$, comprise where a parent has been born and parents' educational level, as well as the number of books in the household. The school or institutional variables $(Z)$ include school size, the share of females in the school, student/teacher ratio, share of certified teachers, ratio of computers to students, whether a school is private or public as well as its location (urban or otherwise $)^{24}$.

To look at whether the explanatory variables affect individuals differently contingent on their position in the educational scores distribution, we also estimate quantile regressions, using the $10^{\text {th }}, 50^{\text {th }}$ and $90^{\text {th }}$. In contrast to the OLS mean regression, a median regression estimator minimizes the sum of absolute errors instead of squared errors. Correspondingly, all other conditional quantile functions minimize an asymmetrically weighted sum of absolute errors ${ }^{25}$. Throughout, we report results from the baseline OLS specification as well as from the $10^{\text {th }}$, median and $90^{\text {th }}$ quantiles.

\footnotetext{
22 For TIMSS 1995 and 1997, 25 country dummies are introduced; for the later rounds, 36.

${ }^{23}$ Results available on request

${ }^{24}$ Not that with the TIMSS estimates reported in the appendices, we have slightly different variables available both relative to PISA and across the two panels.

${ }^{25}$ For a discussion of the properties of quantile regressions, see Buchinsky (1998). Applications can be found, inter alia, in Chamberlain (1994), Eide and Showalter (1998), Fertig and Schmidt (2002)
} 
Tables 1a-1c provide results with the PISA data estimated separately for each of the three disciplines. Several things stand out. In the first place, family background variables have a strong, significant association with educational scores. In particular, parents with low education and/or being born abroad has a clear negative association with scores, suggesting that migrants may do systematically worse in tests. This conclusion is reinforced by the finding that speaking the test language at home is also positive and highly significant for all disciplines. This appears to have the largest effect for the lowest quantile. Similarly, having many books at home has a strong positive association with a student's performance.

Turning to the institutional variables, as regards school location, being in a larger towns or city is associated with higher scores in all disciplines. A higher ratio of students to teachers is consistently negatively signed, with the coefficient being larger for the upper quantile. Having a higher share of certified teachers is unambiguously good for test scores across all disciplines, as is having a higher share of girls among the students. In terms of school ownership, being private has no clear association with educational outcomes. An indicator of school resources - the ratio of PCs to students - seems to be significantly correlated with reading scores but not robustly with scores in the other disciplines. The results of the pooled regressions are confirmed when implementing using cross sections. Although there are shifts in the size of coefficients across years, the signs are largely stable and congruent with those from the pooled model ${ }^{26}$.

Appendix Tables 1a-1d contain similar estimations for science and mathematics for the pooled TIMSS data. The results broadly confirm the findings from the PISA estimates whether with regard to the sign and significance of family background variables or institutional features of the school. Due to the nature of the available variables, we are able to explore more the effect of greater autonomy, such as a school having its own mathematics or science curriculum. More autonomy seems to be associated with better scores, while budget shortfalls for instructional material act adversely on the test score. Interestingly, for 2003 and 2007, we can look at school composition effects. We find that having a higher share of disadvantaged children has a clear negative association with

\footnotetext{
${ }^{26}$ These estimates are available on request.
} 
scores. Indeed, the effect of moving from a high $(>50 \%)$ to a low $(<10 \%)$ share is both large and highly significant ${ }^{27}$.

We now extend the analysis by looking at how Russian scores relate to the rest of the sample in the pooled dataset. We do this by interacting each of the explanatory variables with a Russia dummy. Table 2 reports the results using only the $50 \%$ quantile. It shows that with regard to most explanatory variables, the interaction terms mostly indicate an amplification of the association between that variable and performance in the Russia case. The exceptions are the number of books at home, the share of certified teachers and the ratio of PCs to students where the signs of the interaction term switch and where each of these variables has a smaller association in Russia relative to other countries.

\subsection{Within-country estimates for Russia}

We now shift the analysis and use only Russian data to look at within-country variation.

We start by running pooled estimations before exploring further some cross-sections.

The latter also allows us to use explanatory variables that are available only in particular years. Unfortunately, although both PISA and TIMSS are collected at a regional level, neither dataset provides region identifiers, except in the case of PISA 2009.

Table 3 presents the pooled estimates for mathematics, reading and science using PISA. For brevity, the results for only the $50 \%$ quantile are reported. It can be seen that student-specific variables, such as age and gender have explanatory power. Age and being female mostly enters negatively and is often significant. Being female has a clear negative impact on maths scores and to a lesser extent on science scores, at least for the $90 \%$ quantile. The reverse is true for reading where females perform better and across the distribution. The variables for the individual or family's migration status are mostly insignificant. However, speaking the test language at home is positive and highly significant for all disciplines. This has the largest effect for the lower quantiles. Having many books at home has a strong positive impact on a student's performance and there is relatively little variation in the coefficient sizes across quantiles. As with the pooled

\footnotetext{
${ }^{27}$ Freeman et al (2010) use the 2007 TIMSS to estimate the relationship between scores and characteristics separately for each country, rather than by pooling. They also find large cross-country variation in the impact of background on educational scores. The Russia coefficients for the amount of books at home and parents' education are not trivial, being at around the median point for the latter. There is a small positive coefficient on the female variable and no apparent effect from the native-born dummy.
} 
country estimates, having a parent with low education predictably exerts a negative and significant effect.

With regard to the institutional variables, the estimations paint a more mixed picture. School location unambiguously affects performance with students located in larger towns or cities doing consistently better ${ }^{28}$. Indeed, performance declines almost monotonically with the size of the location in which the student studies. School size is linked with a small but consistently positive impact on scores while a higher ratio of students to teachers is consistently negative. However, the computer/student ratio is always insignificant, while the share of certified teachers appears to have some positive association only with reading and science. Interestingly, a school being in private ownership is negative and significant. This may result from the fact that outright privatisation of schools has been very limited in Russia (although de facto privatisation of many school functions is widespread) with private schools not offering any quality premium.

Looking at this evidence for Russia, variables capturing the student's background, as well as school or institutional features are, as in the pooled cross-country estimates, important in individual performance. Students whose parents are poorly educated and/or have fewer books at home do unambiguously worse at these tests, while being schooled in a village or small town also has a negative association with performance. Resource based views gain some credence, in that fewer teachers and, in some cases, fewer certified teachers have a deleterious effect on scores. Private ownership also has a negative effect. With TIMSS data, Appendix Tables $2 a-2 b$ report results that are largely consistent with those using PISA.

In an extension of this analysis using individual cross-sections for 2000, 2003, 2006 and 2009 the broad findings reported here are upheld. In addition, some additional variables available for selective years can be used. Thus, in 2000 and 2003 having a parent in full time work had positive association with scores for all disciplines, although this was weakest for the $90^{\text {th }}$ quantile. Having a parent with tertiary education similarly had a strong positive association. Turning to measures of pedagogy or school management, the 2003 data allow looking at whether the number of instructional weeks and the frequency of testing have any association with scores. Both variables have a

\footnotetext{
${ }^{28}$ We would have liked to control for region or oblast but were unable as yet to get the data from the Russia national teams collecting the data.
} 
negative impact, although this is not always significant. Having streaming for students appears to have had a positive impact, particularly for mathematics scores in 2006, but had no impact when used in the 2003 cross-section estimate. A measure of greater school autonomy - derived from responses to questions concerning school level discretion over decisions on admissions, as well as hiring/firing and compensation of teachers - has some positive - but weak - correlation with scores with varying significance over disciplines and years. The 2006 round further introduced indicators for the extent to which a school was responsible for allocating resources and its curricula. Interestingly, greater autonomy by these measures has no evident impact on scores suggesting that decentralisation has not necessarily yielded beneficial results. Indeed, both private ownership and delegation appear not to have had any significant positive effect on scores in Russia.

We also explore the sub-national dimension using the 2009 PISA data where region or oblast identifiers are available ${ }^{29}$. As shown by the distributional plot of the mathematics scores in Figure 8, the main cities of Moscow and Saint Petersburg largely dominate other regions. This is also confirmed by quantile and OLS regressions where a dummy for the city of Moscow and Saint Petersburg is positive and significant, indicating that students in these cities perform consistently better then students from other regions ${ }^{30}$.

Finally, the quantile regressions generally suggest that there are relatively few statistically significant differences between different parts of the performance distribution regarding the impact of individual and family background variables. Estimating interquantile differences - specifically the 90\%-10\% difference - for the different discipline scores - for individual and family background variables in PISA, only age and sex and having many books at home have any significant differential effect. With TIMSS, among individual attributes, age and sex have some statistically different impact for the $10^{\text {th }}$ versus the $90^{\text {th }}$ quantiles $^{31}$. With regard to school level variables, the PISA results again pick out almost no significant differences, except for the share of girls in a school and, in

\footnotetext{
${ }^{29}$ In Russia, PISA is implemented in a three stage sampling. In the first stage, geographical areas are sampled using probability proportional to size sampling. In the second stage, schools are sampled and finally, students are sampled within schools.

${ }^{30}$ Results available on request

${ }^{31}$ For brevity, we do not report the results from the inter-quantile differences for reading, mathematics and science estimated using both PISA and TIMSS data.
} 
the case of reading, the ratio of computers to students. With TIMSS, some of the location variables matter differentially as does shortage of teaching materials.

What do the Russian estimates tell us that are different from the pooled, crosscountry estimates? The answer is that the same individual and family background variables have explanatory power but it is with respect to the school or institutional features that differences enter. In particular, private schools have no positive impact on scores, the effects of teacher certification are either absent or weak, while the impact of financial resources - whether in aggregate or disaggregated - has a smaller and less significant association than in the larger multi-country estimates. Other factors, such as the student/teacher ratio, the share of girls, the location of the school and the share of disadvantaged students maintain similar signs and significance as in the larger sample. With the TIMSS data, having some autonomy over the curriculum is associated with better mathematics and science scores.

\subsection{Multilevel specification}

PISA and TIMMS have a multistage sampling design where schools are sampled first followed by students. As such, the dataset has multi-levels that may be selected with unequal probabilities that may make estimates, such as those we have used above, biased. One way to deal with this is to use sampling weights in a multilevel linear model ${ }^{32}$, aimed at modelling the natural clustering of observations in groups (e.g. students in schools). Below, we use a two level random intercept model where the response $y_{i j}$ of unit $i$ in cluster $j$ can be specified as follows,

$$
v_{i j}=x_{i j}^{\prime} \beta+z_{i j}^{\prime} \zeta_{j}
$$

$x_{i j}^{\prime}$ and $z_{i j}^{\prime}$ are vectors of the explanatory variables, $\beta$ are the fixed regression coefficient and $\zeta_{j}$ are the multivariate random effect varying over cluster. $\beta$ contains cluster specific effects of the covariates $x$ given the random effects $\zeta_{j}$.

Table 4 report results from the Russia pooled PISA data. It can be seen that the signs and significance closely replicate the results we have reported above. There are some differences, for example in PISA being located in a village is the only location

\footnotetext{
32 Hesketh and Skrondal 2006
} 
variable that is significant in the case of mathematics. Yet, overall these estimates strongly confirm our earlier estimates that do not explicitly take into account the multilevel nature of the data. The TIMSS random intercept estimates indicate that student/teacher ratios, shortage of available resources are associated with lower scores ${ }^{33}$. An indicator of autonomy - whether a school can develop its own math and science curricula enters with a strongly positive and significant sign.

\section{Conclusion}

Our paper has used two large datasets of educational scores - PISA and TIMSS - with repeated cross-sections to look at the association between scores and individual and family attributes as well as school and institutional features. The results presented in the main text of the paper are mostly from PISA due to the way in which scores are measured in that dataset and their cross-country comparability. However, throughout we complement the analysis by use of TIMSS which evaluates relative to a country's curriculum. Our approach involves estimating an education production function using OLS and quantile regressions for a series of pooled datasets with multi-country observations over time. We also use interactions of the explanatory variables with a Russia dummy to examine whether Russia is different and, if so, in what ways. Further, we analyse only the Russia data, pooling across years. As a cross-check, we also estimated discrete regressions using the cross-sectional evidence. Finally, we explicitly took into account the multilevel nature of the data and estimated using random intercepts and school weighting. The results were broadly consistent with our earlier estimates.

Clearly measuring educational achievements across and within countries is challenging for a variety of reasons, some of which we have mentioned above. The crosscountry descriptive statistics highlight - particularly in the case of PISA - that Russia suffers from a relative weakness in reading skills. There has been no improvement over time. In both mathematics and science, Russian scores are un-trended and remain slightly below the OECD core. Moreover - and likely to be particularly relevant when discussing the scope for innovation - top performers account for a relatively low share of students in all disciplines with either a deterioration over time (as with mathematics) or no discernible trend. Put in cross-country perspective, the share of top students in all disciplines has remained very significantly below the leading Asian and European

\footnotetext{
33 TIMSS results available on request
} 
countries, although superior to another leading emerging market, Brazil. Further, in PISA particularly, there is a relatively large dispersion in scores across all disciplines for Russia. While scores from TIMSS show relatively strong performance in both mathematics and science this may be because of the way they are measured, viz., being related to the current curriculum. Given the problems that have been widely reported with the curricula ${ }^{34}$, these scores may flatter.

The paper is able to pin down a robust association between scores and characteristics in common with findings from the wider literature. For the pooled cross country estimations using PISA, we find clear evidence that educational outcomes are robustly correlated with a number of individual and family background variables. For the latter, in particular, the number of books at home and parents' educational level has a strong association. The evidence regarding institutional factors pins down the importance of location - with an unambiguous negative association between scores and size of the location in which a student resides, as well as the student-teacher ratio and the share of certified teachers in a given school. The evidence from TIMSS largely confirms these results with some extensions, due to the nature of the available variables. In particular, measures signalling greater autonomy at the level of the school and the intensity of classes are positively signed and also significant.

When turning to the Russia data from PISA and TIMSS and looking at the within country variation, we find some similarity with the base estimates using the cross-country evidence. Thus, broadly the same individual and family background variables have explanatory power but it is with respect to the institutional measures that the picture becomes more mixed. Location - as in the multi-country sample - matters, while school size seems to have a positive association. Ownership has no significance, although this may well be related to the fact that the number of de jure private schools in Russia is fairly small. There is also some support for a resource-based view in that fewer teachers have an adverse association with scores. The student-teacher ratio is consistently significant. Indeed, looking at the marginal effects in cross-sectional estimates using the Russia PISA data, we found that the elasticity was around -0.1. The cross-sectional evidence also identifies - using a number of variables - greater autonomy, notably with respect to curriculum setting, as being positively related to scores. The quantile regressions suggest

\footnotetext{
${ }^{34}$ See, for example, Canning (2004), as well as various World Bank reports on the educational sector; www.worldbank.org
} 
relatively few significant differences across the distribution, whether from individual, family or institutional factors.

Finally, while measures such as PISA and TIMSS are particularly helpful for cross-country comparison and benchmarking, they are less suitable for designing policy at national or sub-national level. Nevertheless, our paper suggests that aside from persistent and hard-to-shift factors relating to family background, there are a number of policy options that are likely to help student scores. They range from providing additional resources, including facilitating lower student-teacher ratios, to greater autonomy for schools. Local changes to curricula, for example, appear to be positively correlated with scores. The variation in scores across locations (and likely across regions) is substantial. Students in larger urban centres - particularly Moscow and St. Petersburg perform notably better than those in smaller settlements, again suggesting considerable scope for policy driven improvements aimed at reducing the large spatial variation that exists in the country. 


\section{References}

Anderson, J.O., Chiu, M.-H., Yore, L.D 'First cycle of PISA (2000-2006)-international perspectives on successes and challenges: Research and policy directions 2010' International Journal of Science and Mathematics Education 8 (3), pp. 373-388

Ammermueller, A. (2007) 'PISA: What makes the difference?: Explaining the gap in test scores between Finland and Germany' Empirical Economics 33 (2), pp. 263-287

Buchinsky, M., (1998) 'Recent advances in quantile regression models: A practical guideline for empirical research' Journal of Human Resources 33 (1), pp. 88-126

Bray, M. and Boreskaya, N. (2001) 'Financing education in transitional societies: Lessons from Russia and China' Comparative Education 37 (3), pp. 345-365

Brunello, G, Crivellaro, E. and Rocco, L. (2011) 'Lost in Transition? The Returns to Education acquired under Communism', IZA Working Paper 5409

Canning, M. (2004), 'The Modernisation of Education in Russia', World Bank, Washington DC

Card, D. and Krueger, A. B. (1996) 'Labor Market Effects of School Quality:

Theory and Evidence' in Burtless, Gary (ed.), Does Money Matter? The Effect of School Resources on Student Acbievement and Adult Success., Washington D.C.: Brookings Institution, 97-140.

Chamberlain, G. (1994), Quantile Regression, Censoring, and the Structure of

Wages, in Sims, Christopher A. (ed.), Advances in Econometrics, Cambridge, Cambridge University Press, 171-209.

Cooper, S.T., and Cohn, E. (1997), 'Estimation of a Frontier Production Function for the South Carolina Educational Process', Economics of Education Review, 16(3), pp.313-327.

Currie, J and Thomas, D. (1999), The Intergenerational Transmission of "Intelligence": Down the Slippery Slopes of The Bell Curve, Industrial Relations, 38

Dincer, M.A., Uysal, G., (2010) The determinants of student achievement in Turkey, International Journal of Educational Development, Volume 30, Issue 6

Duflo, E., Dupas, P. and Kremer, M. (2009) 'Additional Resources versus Organizational Changes in Education: Experimental Evidence from Kenya', Harvard University and MIT, May

Eide, E. and Showalter, M.H. (1998) 'The Effect of School Quality on Student Performance: A Quantile Regression Approach.' Economics Letters, 58, 345-350.

Fertig, M.,(2003) 'Who's to Blame? The Determinants of German Students' Achievement in the PISA 2000,' IZA DP No. 739 
Fertig. M and Schmidt, C. (2002) 'The role of background factors for reading literacy' IZA Discussion Paper N.545

Goldstein, H. (1987), Multilevel Models in Educational and Social Research, Charles Griffin.

Goldstein, H. (1995), Multilevel Statistical Modelling, Edward Arnold: London.

Haisken-DeNew, J. P. and Schmidt, C. (1997), 'Inter-Industry and Inter-Region

Differentials: Mechanics and Interpretation.' Review of Economics and Statistics, 79, 516-521.

Hanushek, E.A. (1986) 'The Economics of Schooling: Production and Efficiency in

Public Schools.' Journal of Economic Literature, 24, 1141-1177.

Hanushek, E.A., Rivkin, S.G. and Taylor, L.L. (1996), 'The Identification of School

Resource Effects', Education Economics, 4(2), pp.105-125.

Hanushek, E.A. (1997), 'Effects of School Resources on Economic Performance',

Education Evaluation and Policy Analysis, 19(2), pp.141-164.

Hanushek, E. and Luque, J. (2003) 'Efficiency and equity in schools around the world.' Economics of Education Review, 22:481-502

Hanushek, E.A. and Woessman, L., (2009), 'Do better schools lead to more growth? Cognitive skills ,economic outcomes and causation.' IZA Discussion Paper N. 4575

Hanushek, E.A. and Woessman, L., (2010), 'The Economics of International Differences in Educational Achievement.' IZA Discussion Paper N. 4925, May

Khan, S.R., Kiefer, D. (2007) 'Educational production functions for rural Pakistan: A comparative institutional analysis' Education Economics 15 (3), pp. 327-342

Levin, J. (2001) 'Where the Reductions Count: A Quantile Regression Analysis of

Effects of Class Size and Peer Effects on Scholastic Achievement' Empirical Economics, 26, 241-246.

Organisation for Economic Co-Operation and Development (OECD),

Knowledge and Skills for Life: First Results from PIS A 2000. Paris, 2002.

Machin, S. and Pekkarinen, T. (2008) 'Global Sex Differences in Test Score Variability' Science, 28 November 2008:Volume 322(5906): 1331-2

Mayston, D.J. and Jesson, D. (1999), 'Linking Educational Resourcing with Enhanced Educational Outcomes', DfEE Research Report No.179.

Munich, D, J. Svejnar and K. Terrell, (2005) 'Returns to human capital under the communist wage grid and during the transition to a market economy', Review of Economics and Statistics, February 2005, 87, 1, 100-123 
Vignoles, A, R. Levacic, J Walker, S Machin and Reynolds, D. “The relationship between resource allocation and pupil attainment: a review" September 2000, Centre for the Economics of Education

Wilson, P. (2005) "Efficiency in Education Production among PISA countries, with emphasis on Transition Economies" Mimeo,

Woessmann, L. (2003), 'Schooling resources, educational institutions, and student performance: The international evidence' Oxford Bulletin of Economics and Statistics, 65, 117170 
Fig. 1:PISA Reading Scores, 2000-2009

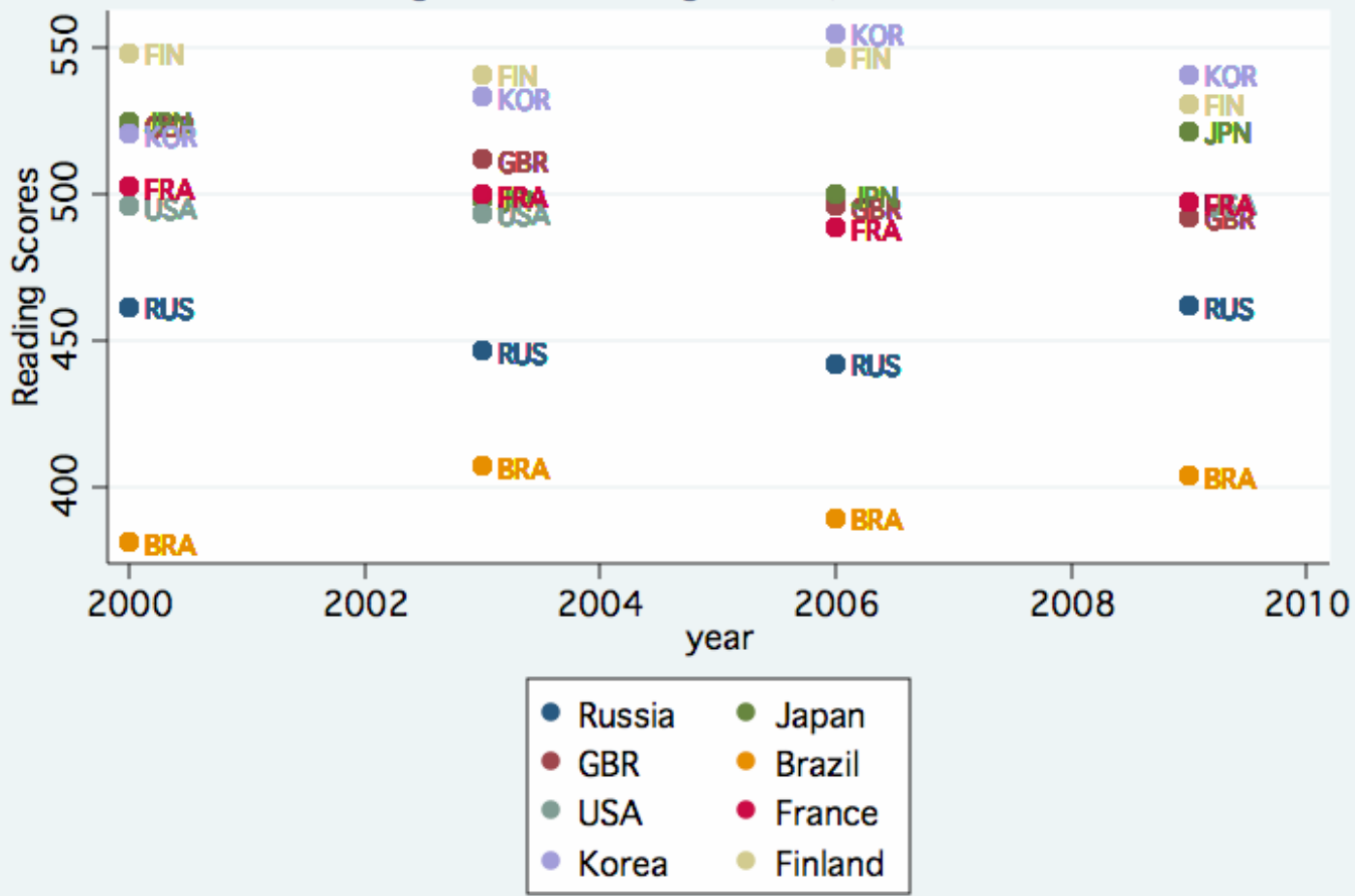

Fig.2:PISA Mathematics Scores, 2000-2009

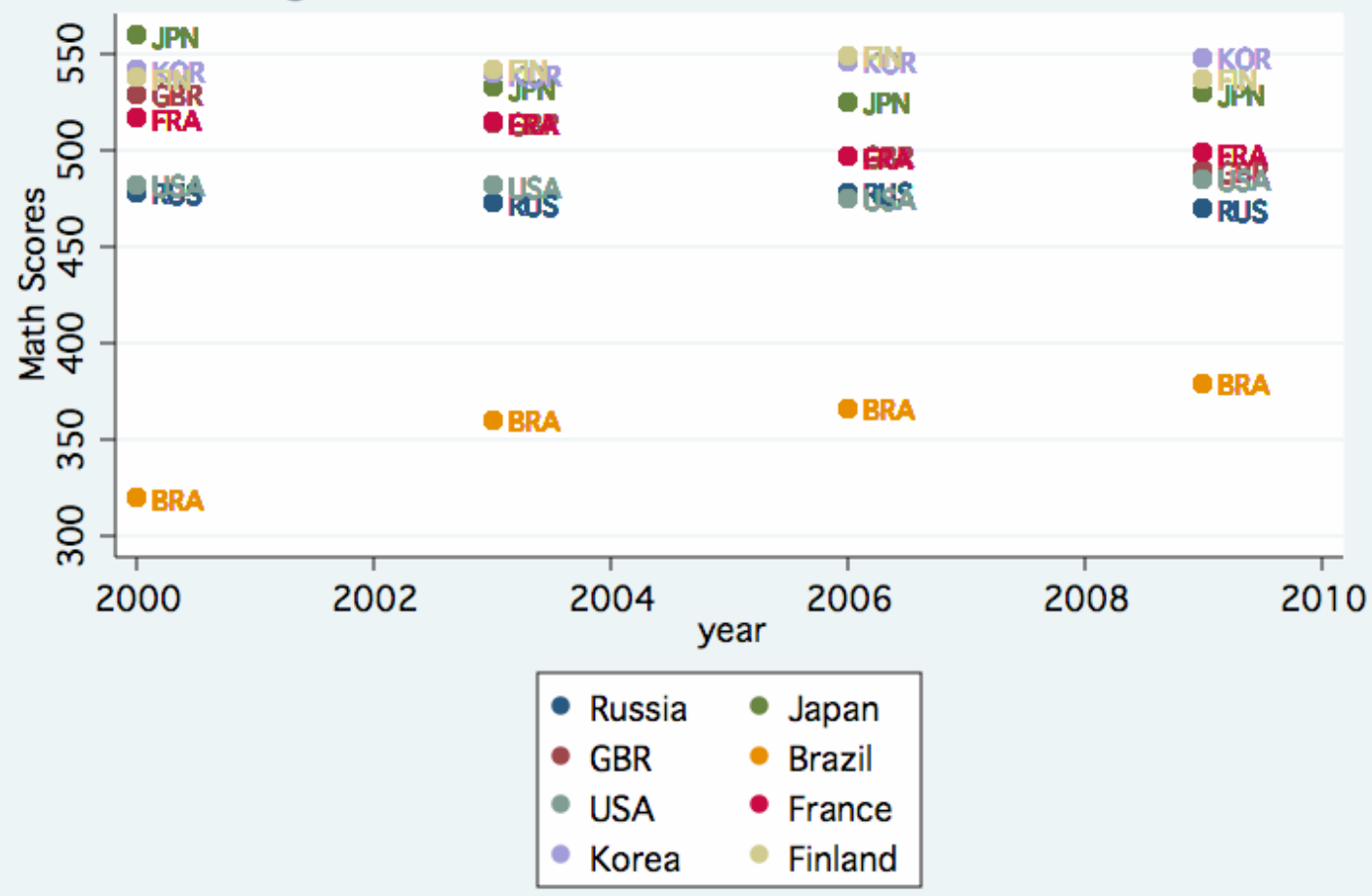


Fig.3:PISA Science Scores, 2000-2009

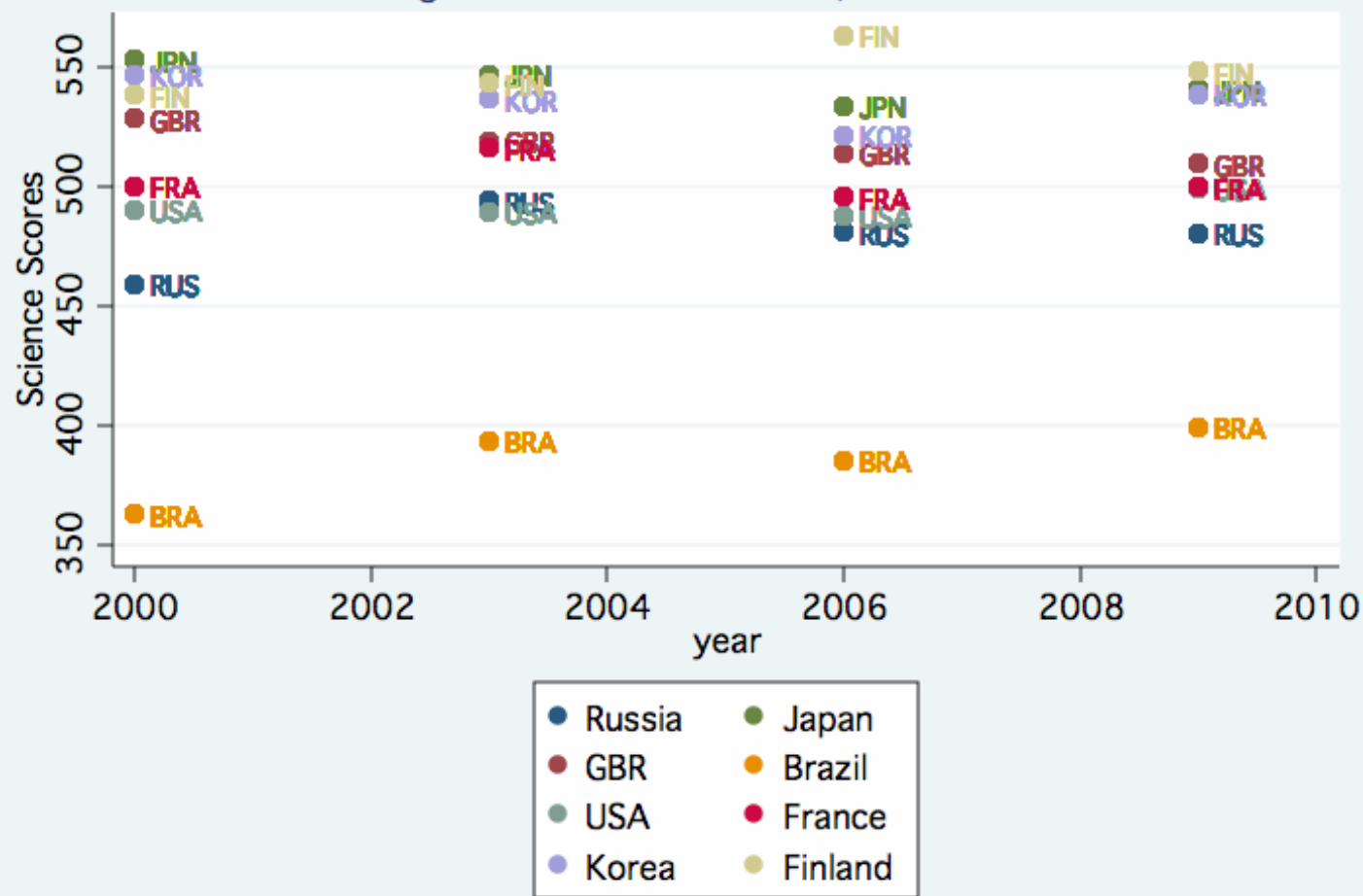

Fig.4: TIMMS Scores, 1995-2007

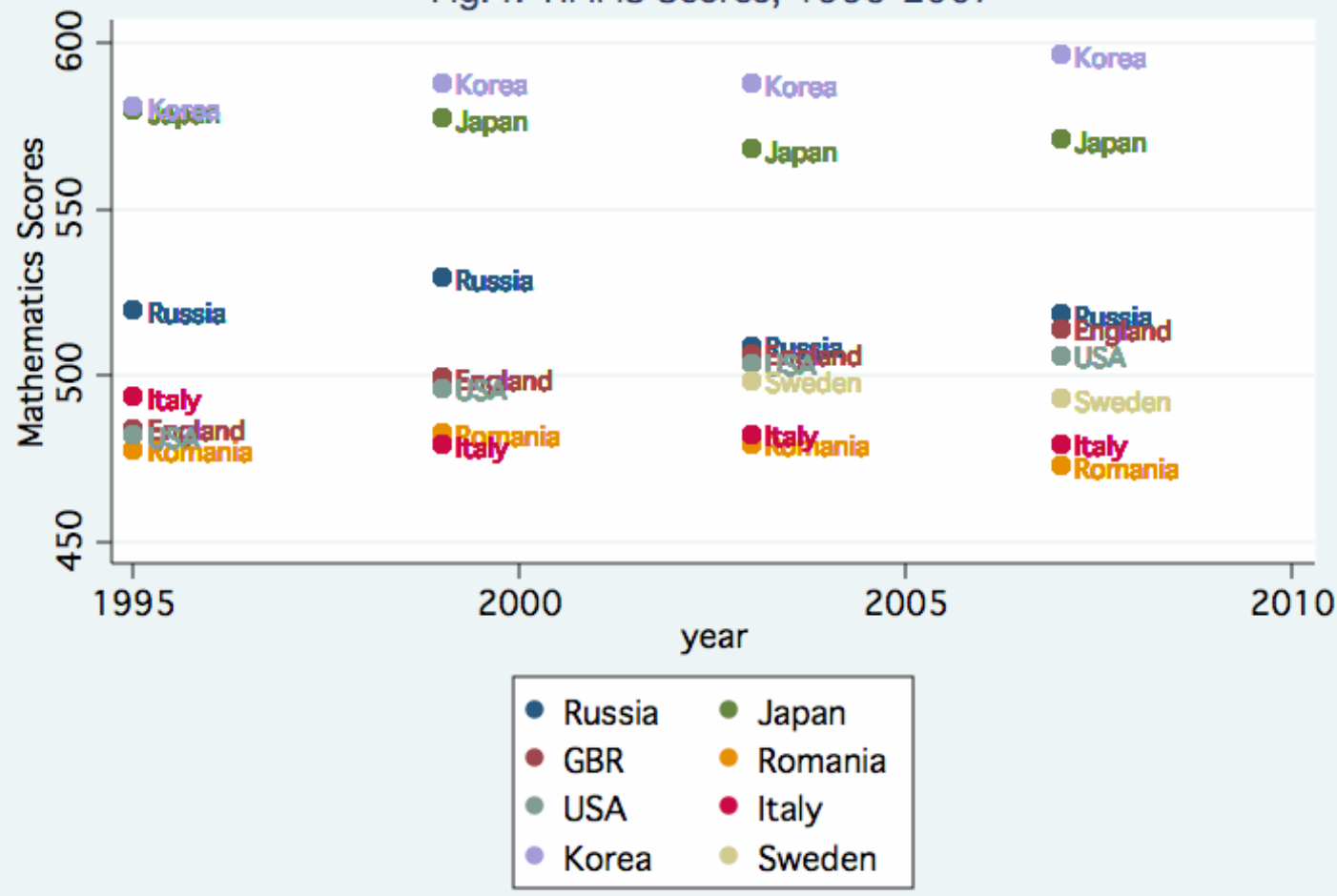




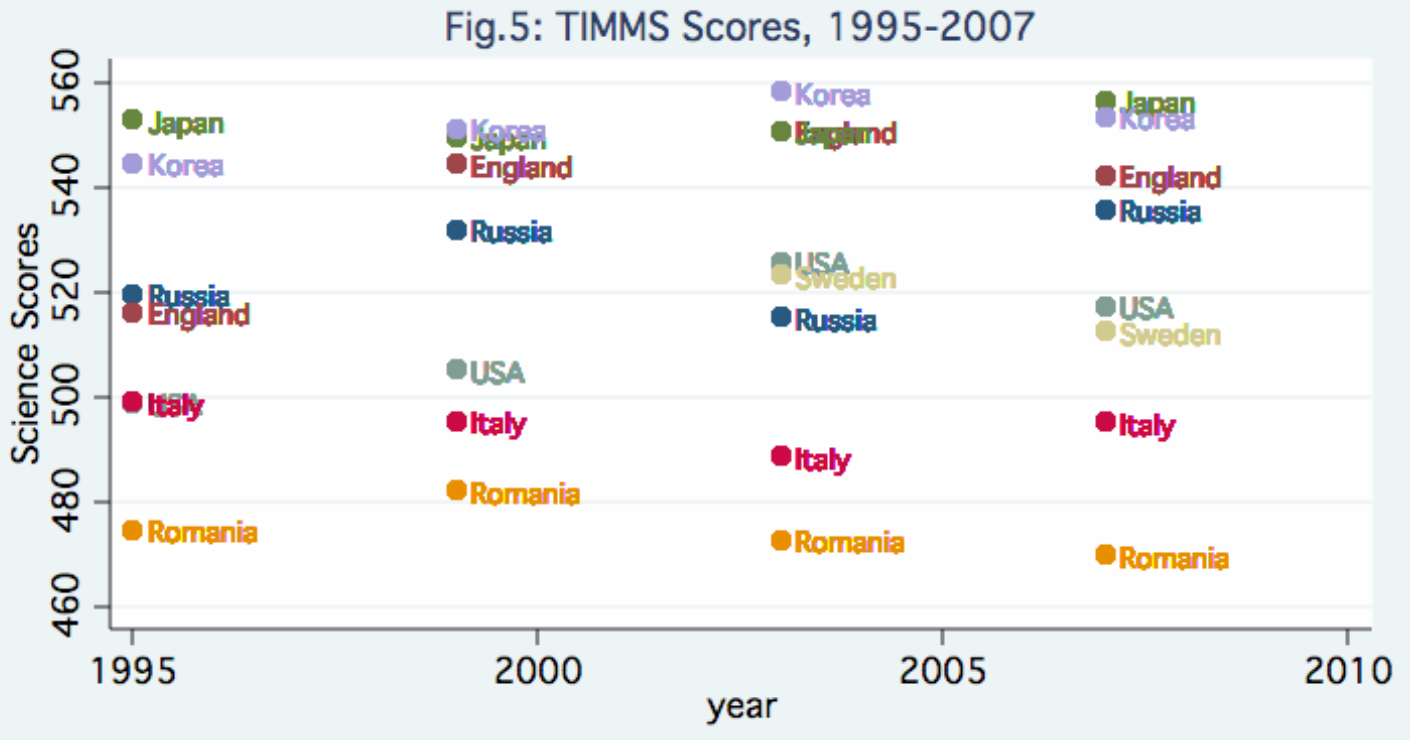

\begin{tabular}{|ll}
\hline - Russia & - Japan \\
- GBR & - Romania \\
- USA & - Italy \\
- Korea & - Sweden
\end{tabular}

Fig.6: Russia Percentage of Top Performers

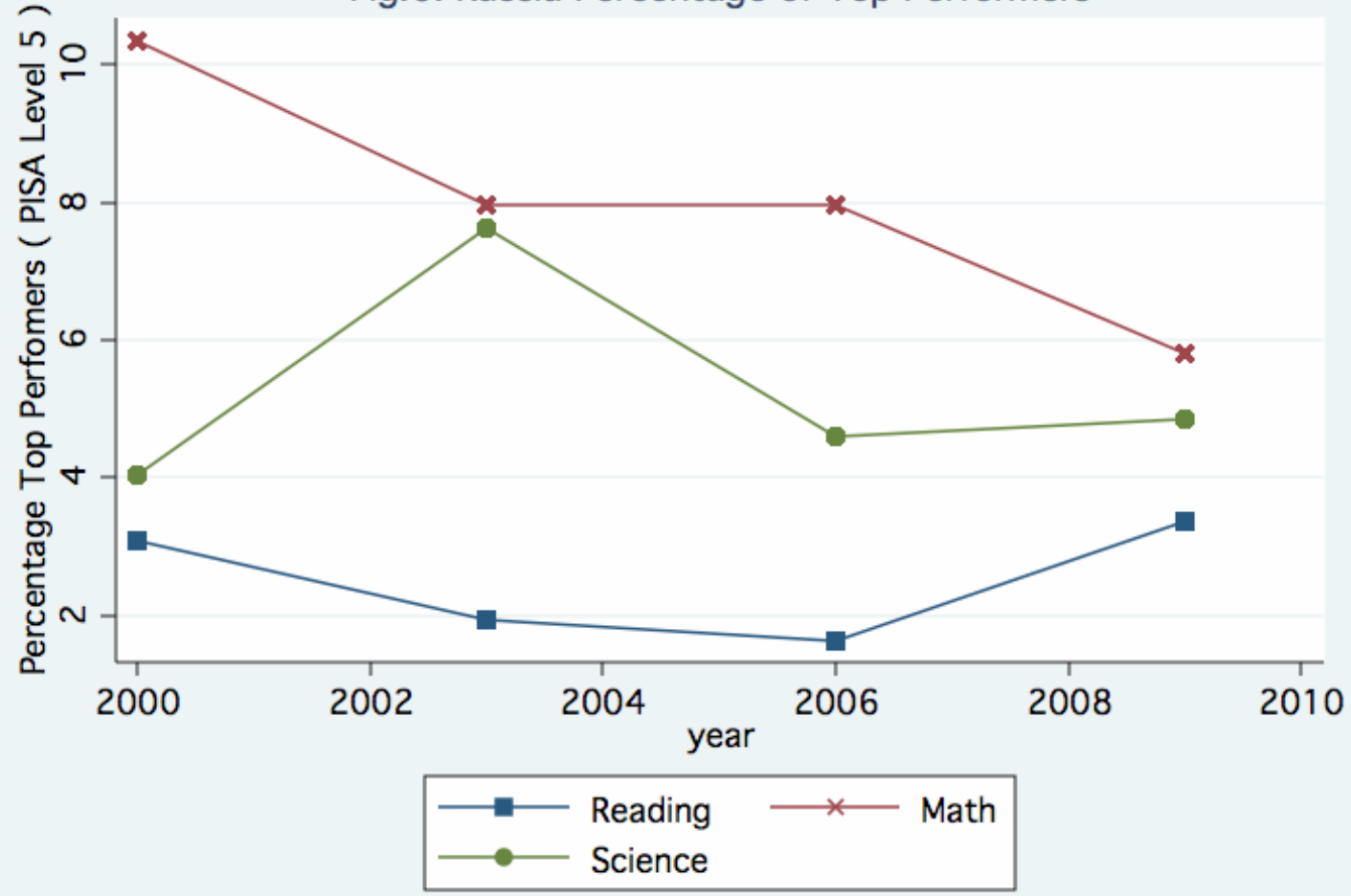


Fig.7: Gender Gap Math \& Reading

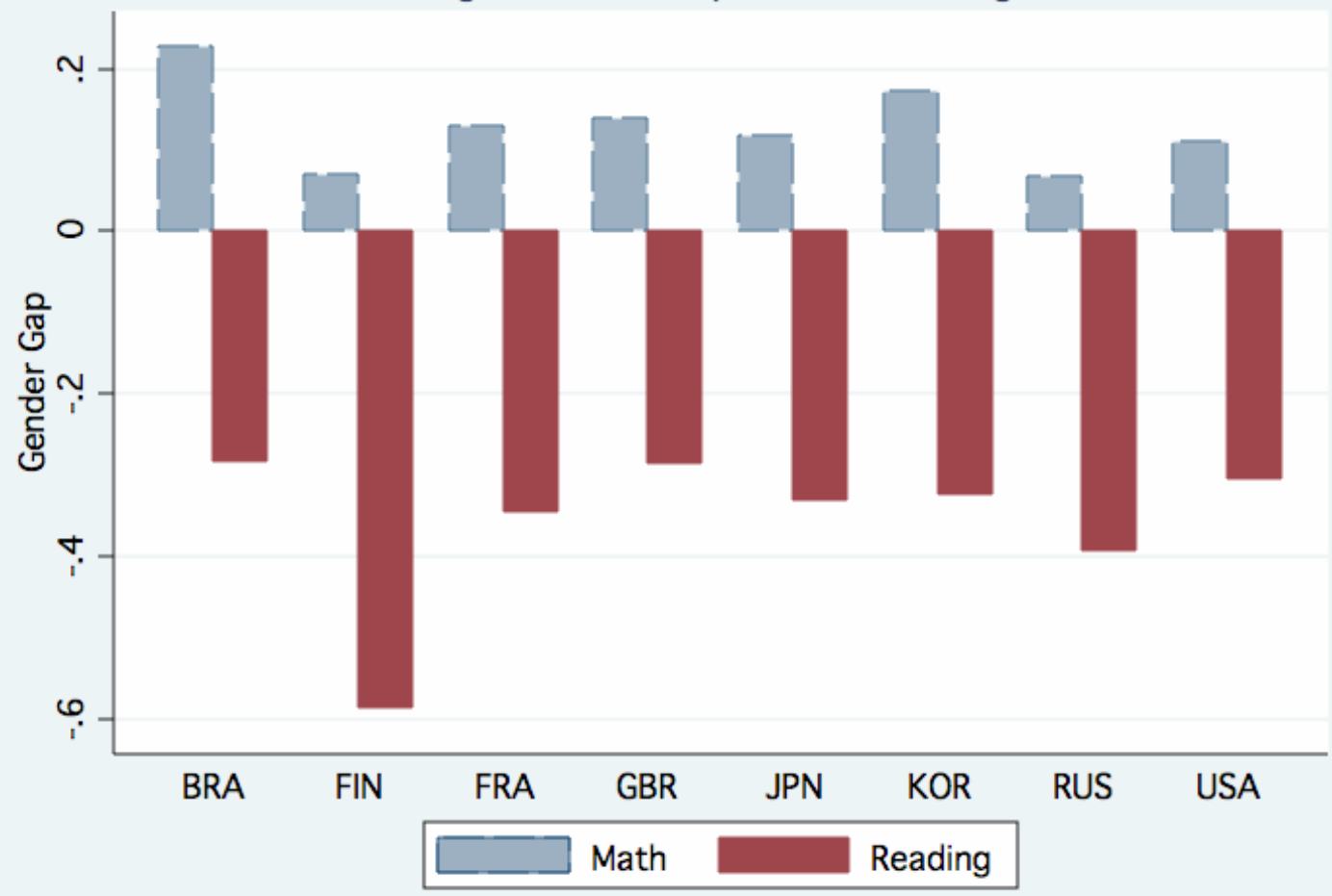

Fig.8: PISA 2009- Russia Region Scores

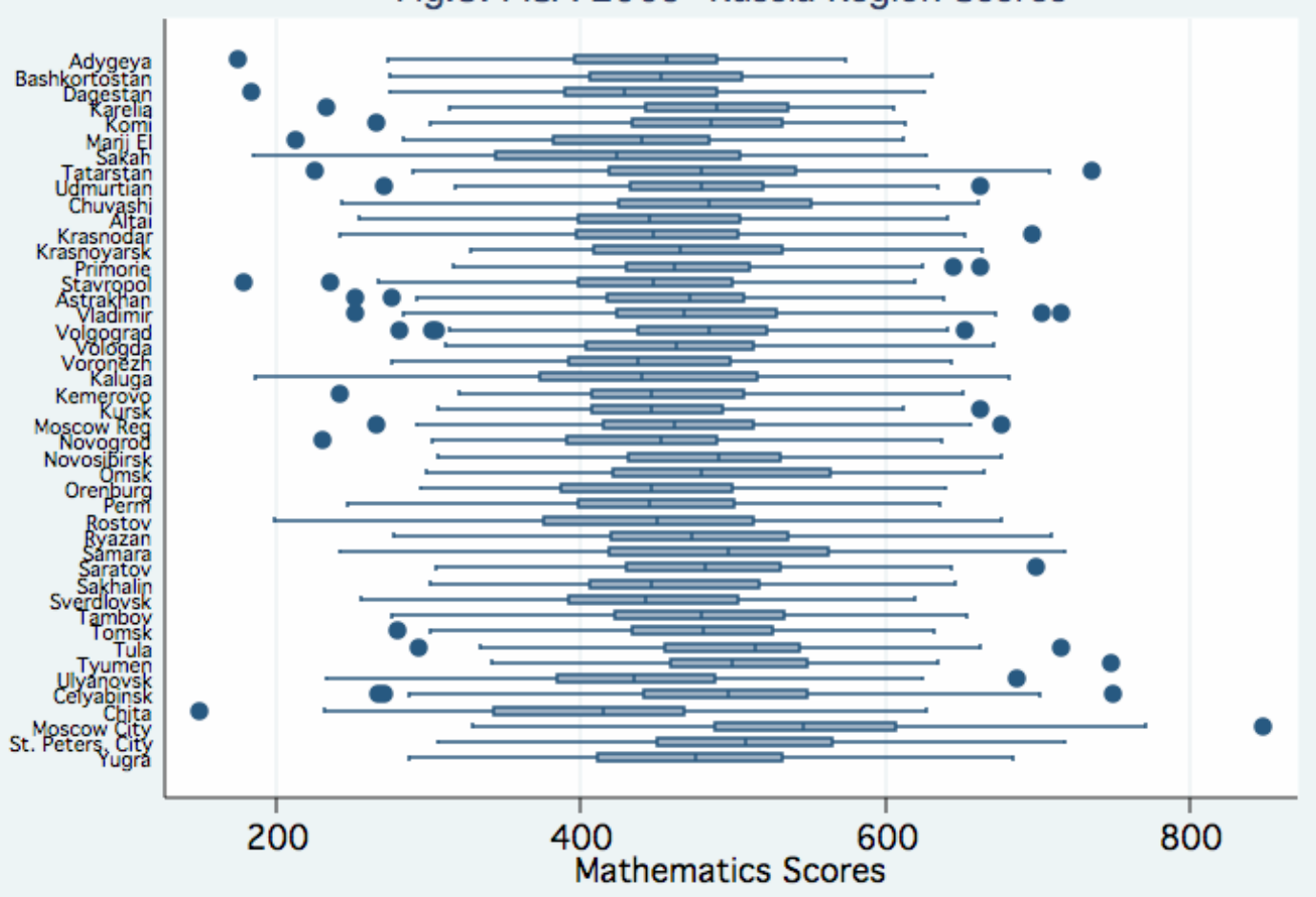

Table 1a PISA Pooled - All Countries

\begin{tabular}{|c|c|c|c|c|}
\hline & OLS & Quantile $50 \%$ & Quantile $10 \%$ & Quantile 90\% \\
\hline VARIABLES & (1) & (2) & (3) & (4) \\
\hline
\end{tabular}

Individual Characteristics and Family Background 


\begin{tabular}{|c|c|c|c|c|}
\hline age & $\begin{array}{c}-10.83 * \star \star \\
(1.124)\end{array}$ & $\begin{array}{c}-11.02 * * \star \\
(1.201)\end{array}$ & $\begin{array}{c}-10.53 * \star \star \\
(1.772)\end{array}$ & $\begin{array}{c}-9.027 * \star \star \\
(1.419)\end{array}$ \\
\hline Female Dummy & $\begin{array}{c}-15.90 * * * \\
(0.626)\end{array}$ & $\begin{array}{c}-15.84 * * * \\
(0.676)\end{array}$ & $\begin{array}{c}-10.93 * \star \star \\
(0.950)\end{array}$ & $\begin{array}{c}-21.70 * * * \\
(0.826)\end{array}$ \\
\hline Student Born in & -2.649 & $-4.083 * \star$ & -2.092 & -0.354 \\
\hline Foreign Country & $(1.766)$ & $(1.856)$ & $(2.454)$ & $(2.357)$ \\
\hline $\begin{array}{l}\text { Mother Born in } \\
\text { Foreign Country }\end{array}$ & $-3.596 * \star$ & $-4.985 * * *$ & $-4.489 * \star$ & -1.697 \\
\hline & $(1.567)$ & $(1.552)$ & $(2.194)$ & $(2.086)$ \\
\hline $\begin{array}{l}\text { Father Born in } \\
\text { Foreign Country }\end{array}$ & $-7.566 * \star \star$ & $-8.945 * \star \star$ & $-9.272 * \star \star$ & $-7.247 \star \star \star$ \\
\hline & $(1.553)$ & $(1.542)$ & $(2.213)$ & $(2.095)$ \\
\hline $\begin{array}{l}\text { Test Language } \\
\text { Spoken at Home }\end{array}$ & $16.35 * \star \star$ & $13.85 * \star \star$ & $15.98 * \star \star$ & $15.12 * \star \star$ \\
\hline & $(0.907)$ & $(0.957)$ & $(1.499)$ & $(1.108)$ \\
\hline Low mother edu & $\begin{array}{c}-14.62 * \star * \\
(0.817)\end{array}$ & $\begin{array}{c}-15.46 * * \star \\
(0.902)\end{array}$ & $\begin{array}{c}-9.920 * * * \\
(1.388)\end{array}$ & $\begin{array}{c}-20.58 * \star \star \\
(0.950)\end{array}$ \\
\hline Low father edu & $\begin{array}{c}-12.53 * * * \\
(0.773)\end{array}$ & $\begin{array}{c}-12.92 * * * \\
(0.868)\end{array}$ & $\begin{array}{c}-7.318 * * * \\
(1.336)\end{array}$ & $\begin{array}{c}-17.04 * * * \\
(0.934)\end{array}$ \\
\hline Many books at home & $\begin{array}{c}35.11 * * * \\
(0.740)\end{array}$ & $\begin{array}{c}35.30 * * * \\
(0.773)\end{array}$ & $\begin{array}{c}36.07 * * * \\
(1.127)\end{array}$ & $\begin{array}{c}29.32 * * * \\
(0.964)\end{array}$ \\
\hline \multicolumn{5}{|c|}{ School Characteristics } \\
\hline Schl size & $\begin{array}{l}0.00600 * \star * \\
(0.000556)\end{array}$ & $\begin{array}{l}0.00648 * * * \\
(0.000628)\end{array}$ & $\begin{array}{l}0.00492 * * * \\
(0.000925)\end{array}$ & $\begin{array}{l}0.00612 * * * \\
(0.000613)\end{array}$ \\
\hline PC girls & $\begin{array}{c}16.52 * * * \\
(1.596)\end{array}$ & $\begin{array}{c}14.82 * \star \star \\
(1.704)\end{array}$ & $\begin{array}{c}23.58 * * * \\
(2.424)\end{array}$ & $\begin{array}{c}9.905 * * * \\
(2.059)\end{array}$ \\
\hline Student/teacher & $\begin{array}{c}-0.620 * * * \\
(0.0538)\end{array}$ & $\begin{array}{c}-0.563 * * * \\
(0.0592)\end{array}$ & $\begin{array}{c}-0.513 * * * \\
(0.0871)\end{array}$ & $\begin{array}{c}-0.853 * * * \\
(0.0709)\end{array}$ \\
\hline $\begin{array}{l}\text { Prop certified } \\
\text { teacher }\end{array}$ & $7.704 * \star \star$ & $7.492 * \star *$ & $10.56 * \star *$ & 1.420 \\
\hline & $(1.218)$ & $(1.345)$ & $(1.935)$ & $(1.681)$ \\
\hline Computer/sch size & $\begin{array}{c}0.187 \\
(0.695)\end{array}$ & $\begin{array}{c}0.302 \\
(0.566)\end{array}$ & $\begin{array}{c}-19.39 * * * \\
(0.339)\end{array}$ & $\begin{array}{c}1.483 \\
(0.996)\end{array}$ \\
\hline Private school & $\begin{array}{l}-0.289 \\
(1.179)\end{array}$ & $\begin{array}{l}-2.298 * \\
(1.313)\end{array}$ & $\begin{array}{c}0.414 \\
(1.797)\end{array}$ & $\begin{array}{l}-1.663 \\
(1.607)\end{array}$ \\
\hline Village & $\begin{array}{c}-2.547 * \star \\
(1.068)\end{array}$ & $\begin{array}{c}-2.936 * \star \\
(1.185)\end{array}$ & $\begin{array}{l}3.252 * \star \\
(1.608)\end{array}$ & $\begin{array}{c}-7.217 * \star \star \\
(1.406)\end{array}$ \\
\hline Small Town & $\begin{array}{c}-3.687 * \star * \\
(0.841)\end{array}$ & $\begin{array}{c}-5.479 * * * \\
(0.918)\end{array}$ & $\begin{array}{c}2.075 \\
(1.306)\end{array}$ & $\begin{array}{c}-6.379 * * * \\
(1.092)\end{array}$ \\
\hline Town & $\begin{array}{c}-1.740 * \star \\
(0.800) \\
(3.961)\end{array}$ & $\begin{array}{c}-2.168 * * \\
(0.849) \\
(1.721)\end{array}$ & $\begin{array}{l}-0.942 \\
(1.232) \\
(2.325)\end{array}$ & $\begin{array}{c}-3.910 * * * \\
(1.048) \\
(2.103)\end{array}$ \\
\hline Constant & $\begin{array}{c}596.9 * * * \\
(18.54)\end{array}$ & $\begin{array}{c}523.6 * * * \\
(19.11)\end{array}$ & $\begin{array}{c}393.3 * * * \\
(28.31)\end{array}$ & $\begin{array}{c}630.2 * * * \\
(22.55)\end{array}$ \\
\hline $\begin{array}{l}\text { Observations } \\
\text { R-squared }\end{array}$ & $\begin{array}{c}430,745 \\
0.429\end{array}$ & 430,745 & 430,745 & 430,745 \\
\hline
\end{tabular}

Robust standard errors in parentheses; $\star \star \star p<0.01, * \star p<0.05, *$ p $<0.1$; Year, Countries and Grades dummy included but not reported. Countries included: AUS, AUT, BEL, BRA, CAN, CHE, CZE, DUE, DNK, ESP, FIN, FRA, GBR, GRC, HKG, HUN, IND, IRL, ISL, ITA, JPN, KOR, LIE, LUX, LVA, MEX, NDL, NOR, NZL, POL, PRT, RUS, SWE, THA, USA.

Table 1b PISA Pooled - All Countries

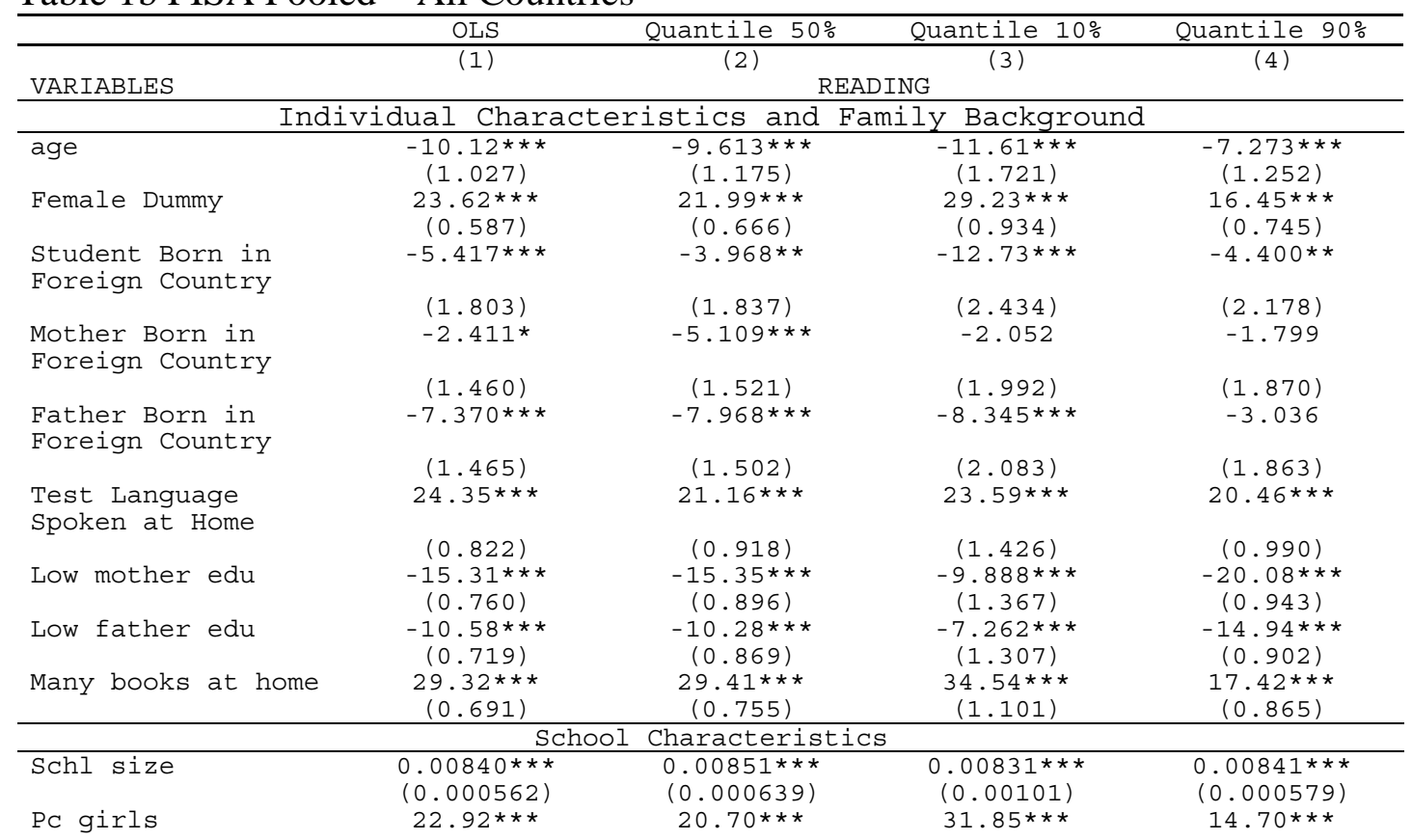




\begin{tabular}{|c|c|c|c|c|}
\hline & $(1.426)$ & $(1.613)$ & $(2.342)$ & $(1.741)$ \\
\hline Student/teacher & $\begin{array}{c}-0.548 * * * \\
(0.0467)\end{array}$ & $\begin{array}{c}-0.555 * * * \\
(0.0568)\end{array}$ & $\begin{array}{l}-0.156 * \\
(0.0806)\end{array}$ & $\begin{array}{c}-0.840 * * * \\
(0.0613)\end{array}$ \\
\hline $\begin{array}{l}\text { Prop certified } \\
\text { teacher }\end{array}$ & $8.090 * \star \star$ & $7.266 * \star \star$ & $11.34 * \star *$ & $6.216 * \star \star$ \\
\hline Computer/sch size & $\begin{array}{l}(1.039) \\
0.836 * * \\
(0.333)\end{array}$ & $\begin{array}{c}(1.272) \\
1.530 * * * \\
(0.420)\end{array}$ & $\begin{array}{c}(1.798) \\
-9.357 * * * \\
(0.245)\end{array}$ & $\begin{array}{c}(1.389) \\
0.836 \\
(0.537)\end{array}$ \\
\hline Private school & $\begin{array}{c}-2.058 * \star \\
(1.041)\end{array}$ & $\begin{array}{c}-4.101 * * * \\
(1.241)\end{array}$ & $\begin{array}{c}-5.251 * \star \star \\
(1.728)\end{array}$ & $\begin{array}{c}-3.154 * \star \\
(1.415)\end{array}$ \\
\hline Village & $\begin{array}{c}-8.274 * * * \\
(0.980)\end{array}$ & $\begin{array}{c}-9.831 * * * \\
(1.147)\end{array}$ & $\begin{array}{c}-3.815 * * \\
(1.576)\end{array}$ & $\begin{array}{c}-10.96 * * * \\
(1.225)\end{array}$ \\
\hline Small Town & $\begin{array}{c}-9.610 * * * \\
(0.800)\end{array}$ & $\begin{array}{c}-10.38 * * * \\
(0.904)\end{array}$ & $\begin{array}{c}-8.000 * * * \\
(1.327)\end{array}$ & $\begin{array}{c}-10.19 * * * \\
(0.989)\end{array}$ \\
\hline Town & $\begin{array}{c}-4.230 * * * \\
(0.742)\end{array}$ & $\begin{array}{c}-5.062 * * * \\
(0.832)\end{array}$ & $\begin{array}{c}-4.312 * \star * \\
(1.183)\end{array}$ & $\begin{array}{c}-6.919 * * * \\
(0.925)\end{array}$ \\
\hline Constant & $\begin{array}{c}541.7 * * * \\
(16.76)\end{array}$ & $\begin{array}{c}473.9 * * * \\
(18.64)\end{array}$ & $\begin{array}{c}351.7 * * * \\
(27.37)\end{array}$ & $\begin{array}{c}578.0 * * * \\
(19.79)\end{array}$ \\
\hline $\begin{array}{l}\text { Observations } \\
\text { R-squared }\end{array}$ & $\begin{array}{c}482,119 \\
0.373\end{array}$ & 482,119 & 482,119 & 482,119 \\
\hline
\end{tabular}

Robust standard errors in parentheses; $\star \star \star p<0.01, * \star p<0.05, * p<0.1 ;$ Year, Countries and Grades dummy included but not reported. Countries included: AUS, AUT, BEL, BRA, CAN, CHE, CZE, DUE, DNK, ESP, FIN, FRA, GBR, GRC, HKG, HUN, IND, IRL, ISL, ITA, JPN, KOR, LIE, LUX, LVA, MEX, NDL, NOR, NZL, POL, PRT, RUS, SWE, THA, USA.

Table 1c PISA Pooled - All Countries

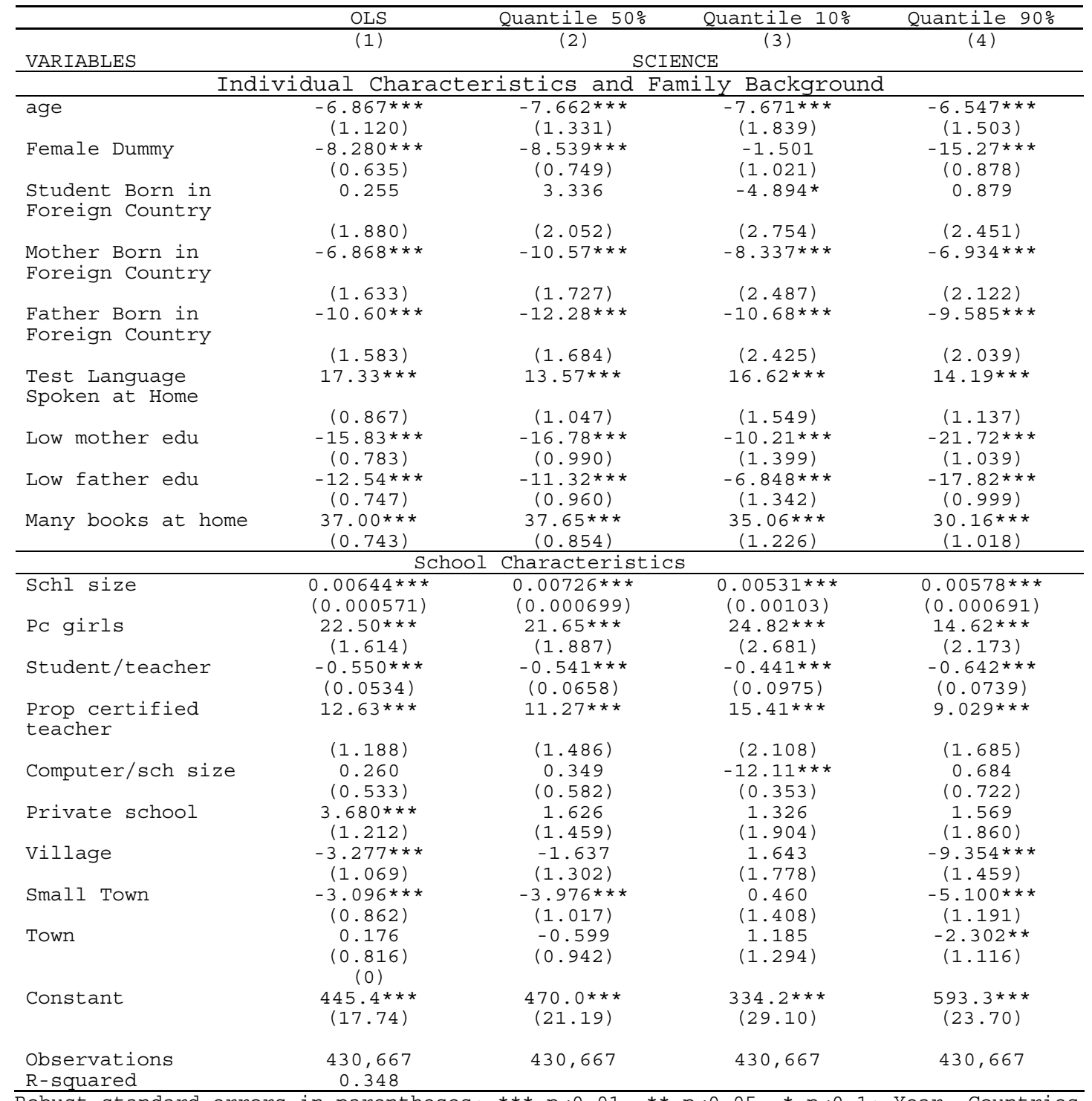

Robust standard errors in parentheses; $\star \star \star p<0.01, * \star p<0.05, * p<0.1 ;$ Year, Countries and Grades dummy included but not reported. Countries included: AUS, AUT, BEL, BRA, CAN, CHE, CZE, DUE, DNK, ESP, FIN, FRA, GBR, GRC, HKG, HUN, IND, IRL, ISL, ITA, JPN, KOR, LIE, LUX, LVA, MEX, NDL, NOR, NZL, POL, PRT, RUS, SWE, THA, USA. 
Table 2 PISA - Russia interactions

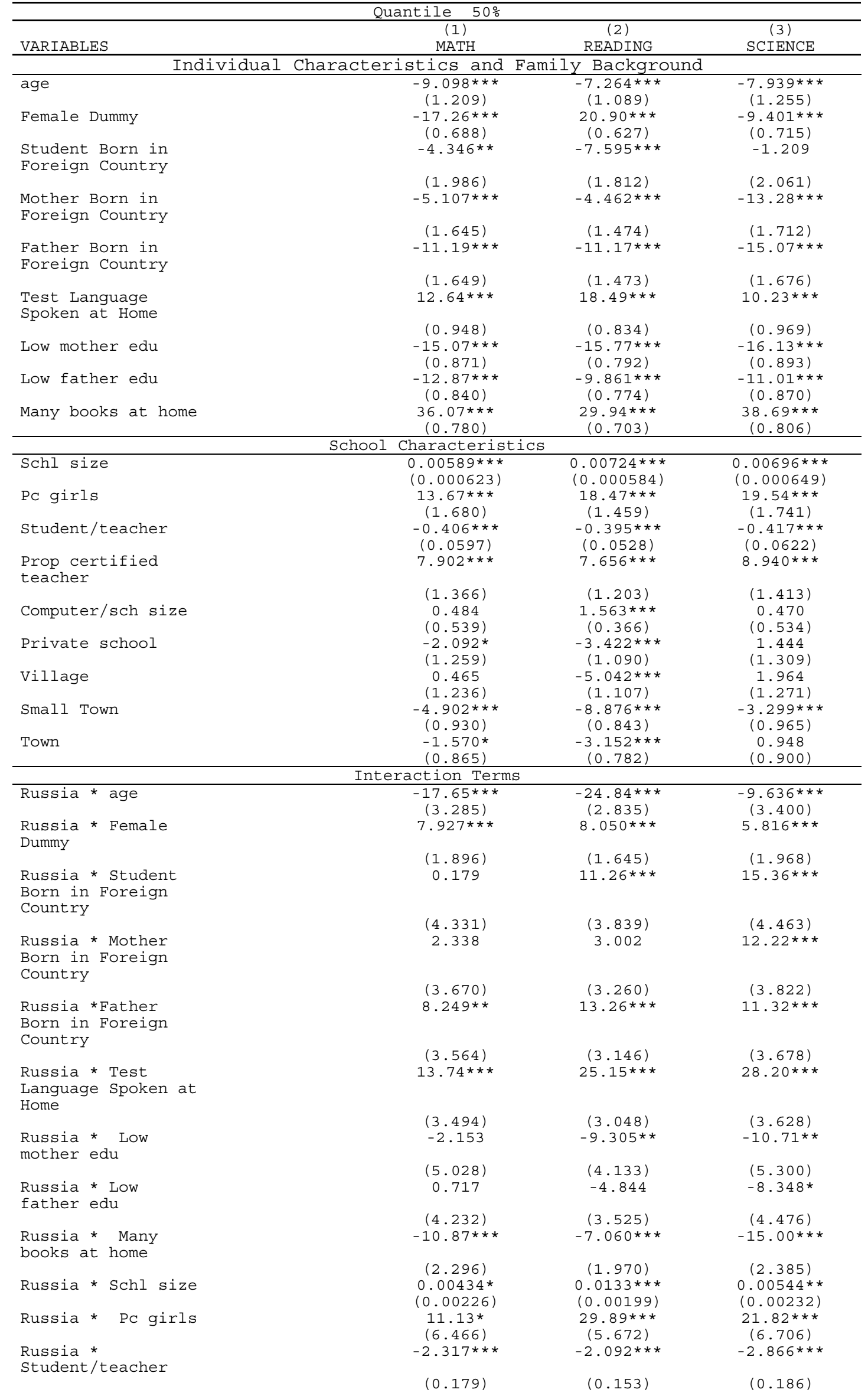




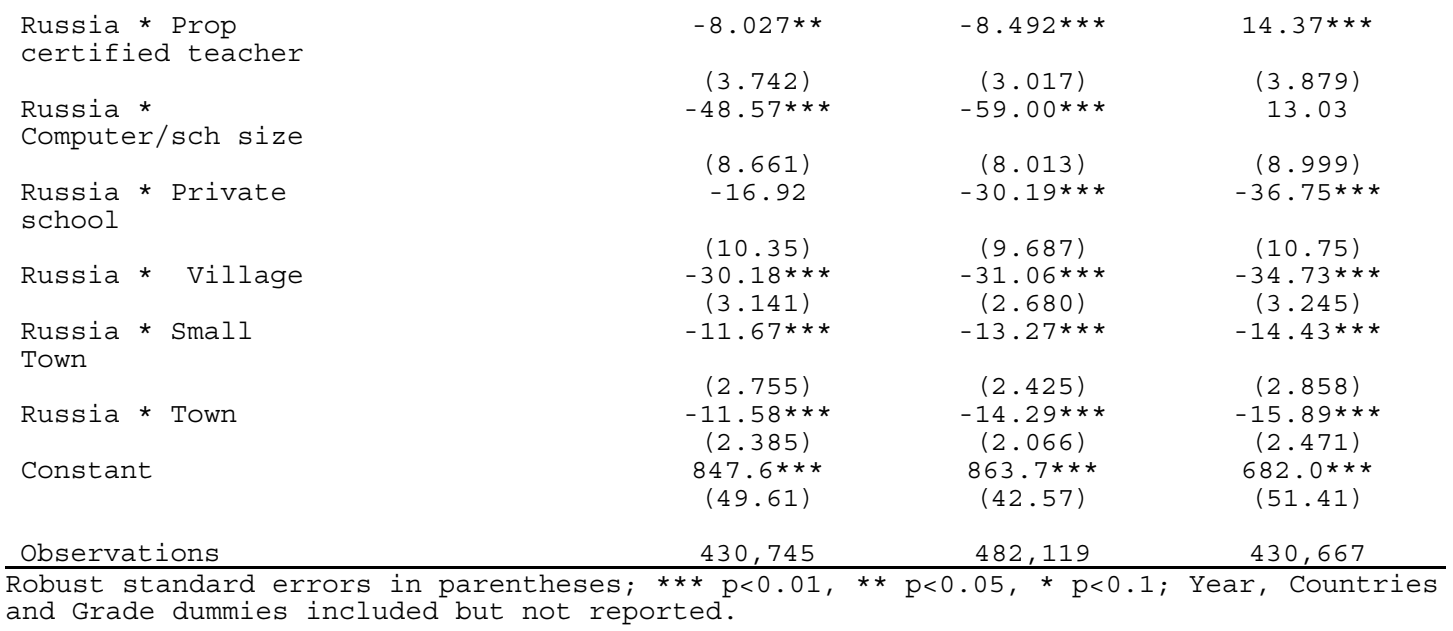

Table 3 PISA Russia estimates

\begin{tabular}{|c|c|c|c|}
\hline \multicolumn{4}{|c|}{ Quantile 50\% } \\
\hline & (1) & $(2)$ & (3) \\
\hline VARIABLES & MATH & READING & SCIENCE \\
\hline \multicolumn{4}{|c|}{ Individual and Family Characteristics } \\
\hline Age & $\begin{array}{c}-21.59 * \star \star \\
(4.295)\end{array}$ & $\begin{array}{c}-19.64 * \star \star \\
(3.742)\end{array}$ & $\begin{array}{c}-14.68 * \star \star \\
(4.318)\end{array}$ \\
\hline Female Dummy & $\begin{array}{c}-9.606 * \star \star \\
(2.225)\end{array}$ & $\begin{array}{c}29.48 * \star \star \\
(1.940)\end{array}$ & $\begin{array}{l}-2.861 \\
(2.243)\end{array}$ \\
\hline Student Born in & -4.499 & 2.777 & $12.22 * \star$ \\
\hline \multicolumn{4}{|l|}{ Foreign Country } \\
\hline \multicolumn{4}{|l|}{$\begin{array}{l}\text { Mother Born in } \\
\text { Foreign Country }\end{array}$} \\
\hline & $(4.127)$ & $(3.712)$ & $(4.188)$ \\
\hline Father Born in & -2.961 & 5.653 & -3.129 \\
\hline Foreign Country & $(3.973)$ & $(3.546)$ & $(4.011)$ \\
\hline \multicolumn{4}{|l|}{ Spoken at Home } \\
\hline & $(4.230)$ & $(3.738)$ & $(4.246)$ \\
\hline Low mother edu & $\begin{array}{c}-17.00 * \star \star \\
(6.229)\end{array}$ & $\begin{array}{c}-24.52 * \star * \\
(5.183)\end{array}$ & $\begin{array}{c}-28.99 * * * \\
(6.355)\end{array}$ \\
\hline Low father edu & $\begin{array}{c}-13.80 * * * \\
(5.229)\end{array}$ & $\begin{array}{c}-17.89 * * * \\
(4.403)\end{array}$ & $\begin{array}{c}-16.80 * * * \\
(5.364)\end{array}$ \\
\hline Many books at home & $\begin{array}{c}26.44 * * * \\
(2.736) \\
\end{array}$ & $\begin{array}{c}22.20 * \star * \\
(2.358)\end{array}$ & $\begin{array}{c}25.33 * \star \star \\
(2.762) \\
\end{array}$ \\
\hline \multicolumn{4}{|c|}{ School Characteristics } \\
\hline Schl size & $\begin{array}{l}0.0106 * \star * \\
(0.00273)\end{array}$ & $\begin{array}{l}0.0214 * \star \star \\
(0.00243)\end{array}$ & $\begin{array}{l}0.0120 * \star \star \\
(0.00275)\end{array}$ \\
\hline PC girls & $\begin{array}{c}29.77 \star \star \star \\
(7.867)\end{array}$ & $\begin{array}{c}43.34 * \star \star \\
(7.001)\end{array}$ & $\begin{array}{c}41.76 * \star \star \\
(7.937)\end{array}$ \\
\hline Student/teacher & $\begin{array}{c}-2.560 * * \star \\
(0.215)\end{array}$ & $\begin{array}{c}-2.729 * \star * \\
(0.186)\end{array}$ & $\begin{array}{c}-2.844 * \star \star \\
(0.217)\end{array}$ \\
\hline $\begin{array}{l}\text { Prop certified } \\
\text { teacher }\end{array}$ & -0.169 & $10.67 * * \star$ & $14.90 * \star \star$ \\
\hline & $(4.682)$ & $(3.759)$ & $(4.711)$ \\
\hline Computer/sch size & $\begin{array}{l}-5.832 \\
(12.10)\end{array}$ & $\begin{array}{c}6.779 \\
(11.49)\end{array}$ & $\begin{array}{c}6.755 \\
(12.23)\end{array}$ \\
\hline Private school & $\begin{array}{l}-14.54 \\
(12.81)\end{array}$ & $\begin{array}{c}-30.41 * * \\
(12.32)\end{array}$ & $\begin{array}{c}-29.55 * * \\
(13.07)\end{array}$ \\
\hline Village & $\begin{array}{c}-29.05 * * * \\
(3.659)\end{array}$ & $\begin{array}{c}-40.77 * \star * \\
(3.140)\end{array}$ & $\begin{array}{c}-29.04 * * * \\
(3.673)\end{array}$ \\
\hline Small Town & $\begin{array}{c}-13.52 * \star * \\
(3.292)\end{array}$ & $\begin{array}{c}-21.68 * \star \star \\
(2.918)\end{array}$ & $\begin{array}{c}-16.09 * * * \\
(3.317)\end{array}$ \\
\hline Town & $\begin{array}{c}-10.97 * * * \\
(2.796)\end{array}$ & $\begin{array}{c}-17.40 * \star * \\
(2.437)\end{array}$ & $\begin{array}{c}-14.20 * * * \\
(2.817)\end{array}$ \\
\hline Constant & $\begin{array}{c}689.7 * * * \\
(70.47)\end{array}$ & $\begin{array}{c}543.8 * * * \\
(61.84)\end{array}$ & $\begin{array}{l}539.2 * * * \\
(70.55)\end{array}$ \\
\hline Observations & 12,719 & 15,308 & 12,716 \\
\hline
\end{tabular}

Robust standard errors in parentheses; $\star \star \star p<0.01, * \star p<0.05, * p<0.1 ;$ Year and Grades dummy included but not reported.

Table 4 PISA: Multilevel estimation 


\begin{tabular}{|c|c|c|c|}
\hline VARIABLES & MATH & READING & SCIENCE \\
\hline Individual c & Characteristics & and Family & Background \\
\hline Age & $\begin{array}{c}17.72 * * * \\
(3.184)\end{array}$ & $\begin{array}{c}12.38 * * * \\
(2.258)\end{array}$ & $\begin{array}{c}15.53 * * * \\
(2.992)\end{array}$ \\
\hline Female dummy & $\begin{array}{c}-12.37 * \star \star \\
(1.775)\end{array}$ & $\begin{array}{c}27.93 * \star * \\
(1.299)\end{array}$ & $\begin{array}{c}-7.654 * * \star \\
(1.932)\end{array}$ \\
\hline $\begin{array}{l}\text { Student born in } \\
\text { foreign country }\end{array}$ & $-5.730 *$ & -3.405 & 2.529 \\
\hline & $(3.400)$ & $(2.919)$ & $(3.910)$ \\
\hline $\begin{array}{l}\text { Mother born in } \\
\text { foreign country }\end{array}$ & -2.590 & -3.521 & -2.124 \\
\hline & $(2.931)$ & $(2.468)$ & $(3.182)$ \\
\hline $\begin{array}{l}\text { Father born in } \\
\text { foreign country }\end{array}$ & -3.581 & 0.652 & -5.136 \\
\hline & $(2.974)$ & $(2.373)$ & $(3.308)$ \\
\hline $\begin{array}{l}\text { Test language at } \\
\text { home }\end{array}$ & $19.05 * * *$ & $27.36 * \star \star$ & $29.28 * * *$ \\
\hline & $(6.642)$ & $(2.909)$ & $(5.110)$ \\
\hline $\begin{array}{l}\text { Low mother } \\
\text { education }\end{array}$ & $-26.27 * \star \star$ & $-22.67 * * *$ & $-35.43 * * *$ \\
\hline & $(5.704)$ & $(5.314)$ & $(5.588)$ \\
\hline $\begin{array}{l}\text { Low father } \\
\text { education }\end{array}$ & $-12.19 *$ & $-10.16 * *$ & $-15.68 * * *$ \\
\hline & $(6.510)$ & $(4.607)$ & $(5.495)$ \\
\hline Many books at & $33.52 * * *$ & $29.20 * \star *$ & $28.04 * \star *$ \\
\hline \multirow{2}{*}{\multicolumn{4}{|c|}{$\frac{(1.918)}{\text { School Characteristics }}$}} \\
\hline & & & \\
\hline School size & $\begin{array}{c}0.00209 \\
(0.00657)\end{array}$ & $\begin{array}{l}0.00451 * \\
(0.00265)\end{array}$ & $\begin{array}{c}0.00135 \\
(0.00586)\end{array}$ \\
\hline $\begin{array}{l}\text { Percentage of } \\
\text { girls }\end{array}$ & 26.96 & $22.72 * \star \star *$ & 17.43 \\
\hline & $(24.89)$ & $(7.881)$ & $(18.88)$ \\
\hline Student/teacher & $\begin{array}{c}-1.621 * * * \\
(0.618)\end{array}$ & $\begin{array}{c}-1.245 * \star * \\
(0.217)\end{array}$ & $\begin{array}{c}-1.494 * * * \\
(0.578)\end{array}$ \\
\hline $\begin{array}{l}\text { Proportion } \\
\text { certified } \\
\text { teachers }\end{array}$ & $16.59 *$ & 8.433 & $17.93 * *$ \\
\hline & $(9.331)$ & $(5.543)$ & $(7.895)$ \\
\hline $\begin{array}{l}\text { Computers/school } \\
\text { size }\end{array}$ & -9.488 & 15.70 & -1.840 \\
\hline & $(28.86)$ & $(12.42)$ & $(25.90)$ \\
\hline $\begin{array}{l}\text { Private School } \\
\text { dummy }\end{array}$ & $-25.52 * *$ & $-40.79 * \star \star$ & $-29 \cdot 93 * * *$ \\
\hline School in village & $\begin{array}{l}(10.33) \\
-9.194 \\
(9.349)\end{array}$ & $\begin{array}{c}(3.963) \\
-18.60 * * * \\
(3.463)\end{array}$ & $\begin{array}{l}(7.778) \\
-17.61 * * \\
(7.349)\end{array}$ \\
\hline $\begin{array}{l}\text { School in small } \\
\text { town }\end{array}$ & -5.352 & $-17.23 * * *$ & $-12.74 * *$ \\
\hline School in town & $\begin{array}{l}(8.805) \\
33.41 \\
(144.8)\end{array}$ & $\begin{array}{c}(3.060) \\
12.98 \\
(31,687)\end{array}$ & $\begin{array}{l}(6.412) \\
18.11 \\
(941.7)\end{array}$ \\
\hline $\begin{array}{l}\text { Lns1 } \\
\text { School }\end{array}$ & $\begin{array}{c}4.385 \\
(0.0102) \\
47.45 \\
(2.387)\end{array}$ & $\begin{array}{c}4.341 \\
(0.00583) \\
41.65 \\
(1.679)\end{array}$ & $\begin{array}{c}4.429 * * * \\
(0.00773) \\
42.34 * * * \\
(2.259)\end{array}$ \\
\hline Observations & 12,719 & 15,308 & 12,716 \\
\hline 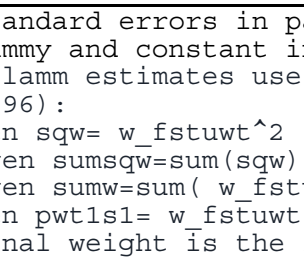 & $\begin{array}{l}\text { parentheses; } * \star \\
\text { included but not } \\
\text { e the following w } \\
\text { 7), by( schoolid2 } \\
\text { tuwt), by ( scho } \\
\text { tt sumw/ sumsqw } \\
\text { inverse of pwt1s }\end{array}$ & $\begin{array}{l}.01, \star \star p \\
\text { ported. } \\
\text { ght (weigh } \\
\text { id2) }\end{array}$ & $\begin{array}{l}\text { 05, * p<0.1; Year and Grade } \\
\text { ng follows Longford 1995a, }\end{array}$ \\
\hline
\end{tabular}




\section{APPENDIX}

Table 1a TIMSS Pooled - All Countries 1995 and 1999

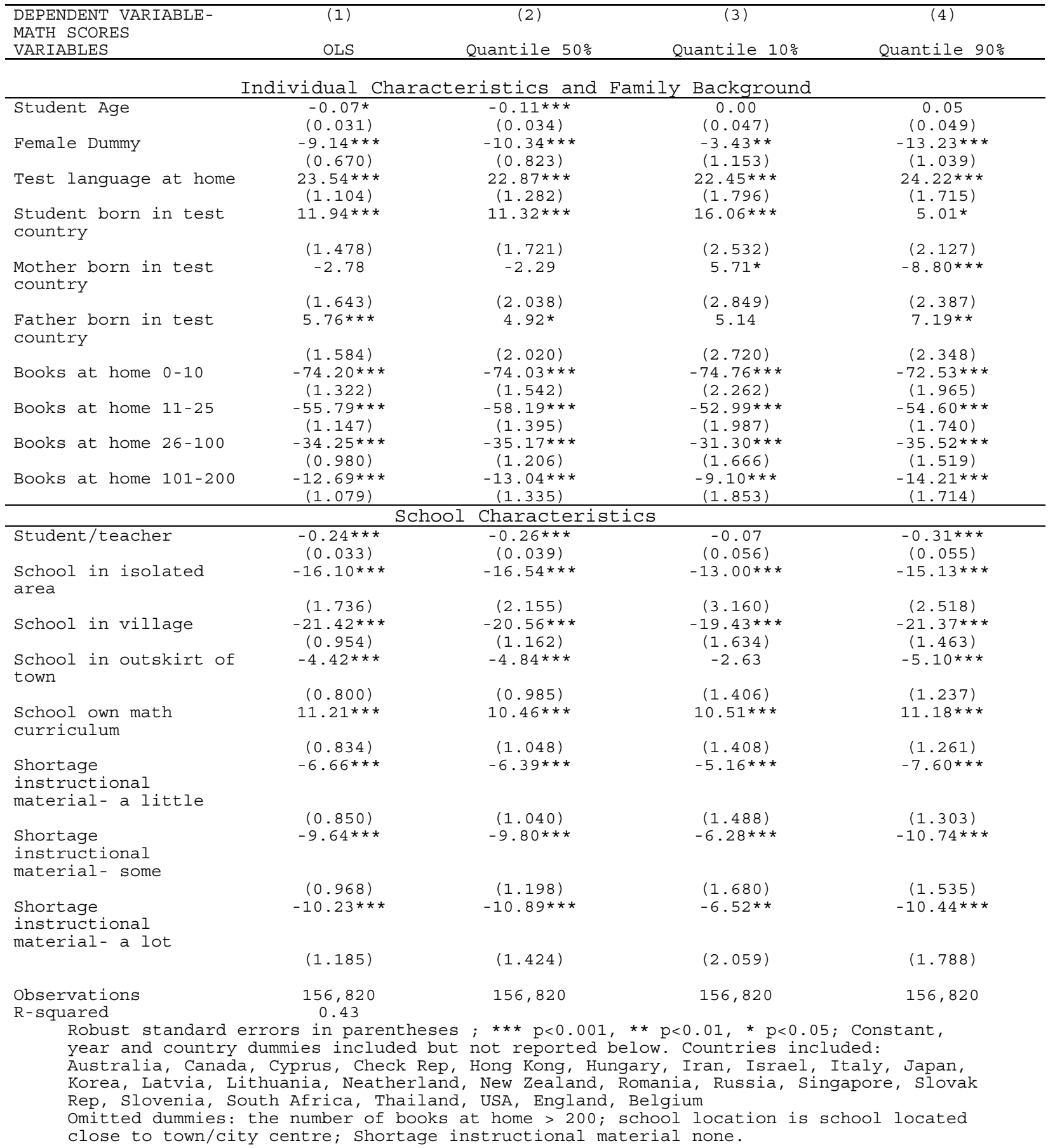

Table 1b TIMSS Pooled - All Countries 1995 and 1999

\section{DEPENDENT VARIABLE-}

SCIENCE SCORES

VARIABLES
(2)

OLS
Quantile 50\%

Quantile 10\%

Quantile 90\%

Individual Characteristics and Family Background

Student Age
Female Dummy

0.05
$(0.032)$

$-20.76 * * \star$

(0.038)

$-22.91 * \star *$

0.01
$(0.048)$
$-13.91 * * *$

$15 * * *$

(0.044)

$-24.41 * \star *$ 


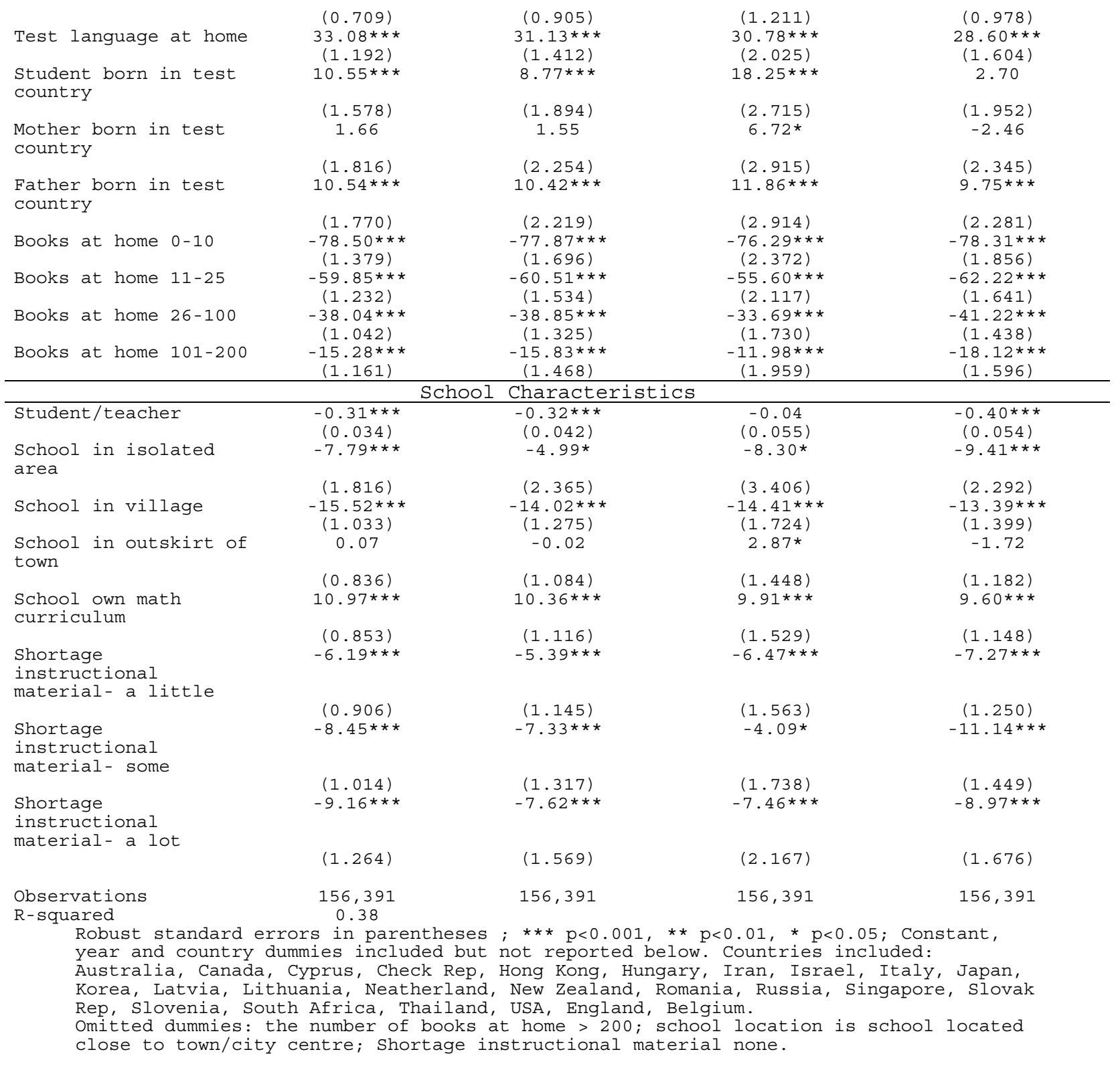

Table 1c TIMSS Pooled - All Countries 2003 and 2007

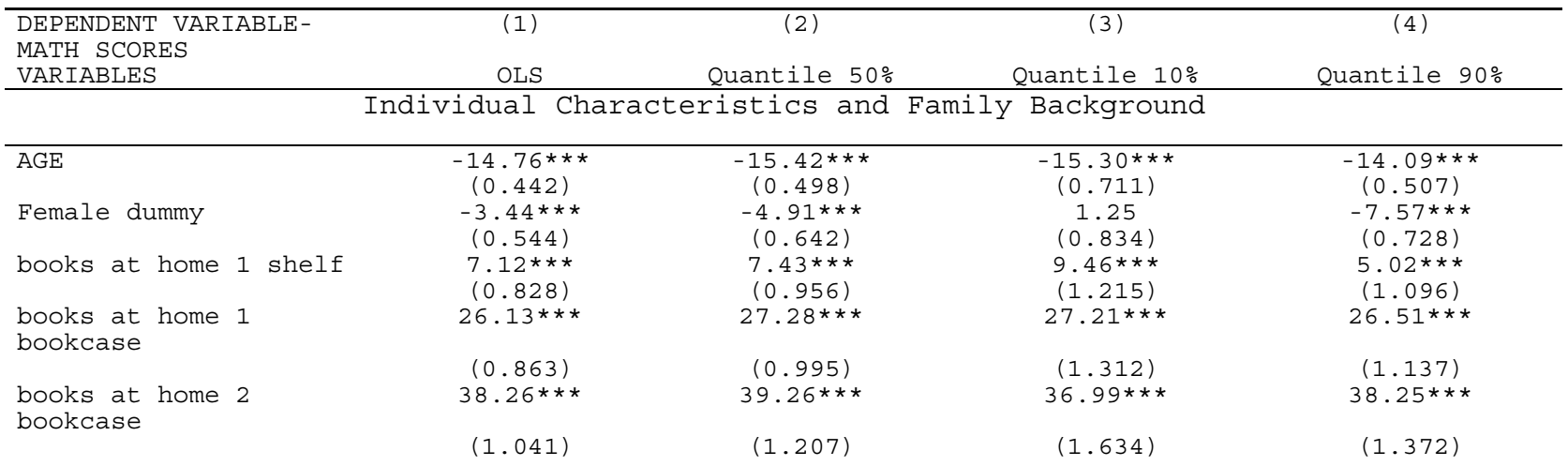


books at home $>=$
bookcase

Mother has ISCED 2

Mother has ISCED 3

Mother has ISCED 4

Mother has ISCED 5

Mother has $1^{\text {st }}$ degree

Mother has $>1^{\text {st }}$ degree

Father has ISCED 2

Father has ISCED 3

Father has ISCED 4

Father has ISCED 5

Father has $1^{\text {st }}$ degree

Father has $>1^{\text {st }}$ degree

mother born in country

of test $=$ no

father born in country

of test $=$ no

student born in country of test $=$ no
$46.21 * * *$

(1.038)

0.73

(0.992)

$7.16 *$ *

(0.935)

$13.31 * \star *$

$(1.005)$

$16.35 * * *$

(1.410)

$23.47 * \star \star$

(1.231)

$16.48 * \star *$

(1.229)

$-1.67$

( 1.030 )

$4.29 * * *$

(0.924)

$6.55 * * *$

(0.981)

$11.24 * * *$

(1.475)

$24.36 * * *$

(1.171)

$20.40 * * *$

(1.125)

$3.49 * *$

(1.320)

$-3.42 * *$

(1.273)

$-38.28 * * *$

$(1.122)$

School in town $>500000$

school in town 100001 500000 PEOPLE

school in town 50001 100000 PEOPLE

school in town $15001-$

50000 PEOPLE

school in town with

$3001-15000$ PEOPLE

$\%$ students

disadvantaged

background: 0-10

\% students

disadvantaged economic

background:11-25

students disadvantaged economic background:2650

math classes are split by group ability

Additional math classes

math remedial classes

Shortage budget for

supply - none

Shortage budget for

supply - little

Shortage budget for

supply - some

Shortage budget for materials- none

Shortage budget for materials- a little

(1.161)

$(1.109)$
$32.69 * \star \star$

$(0.848)$
$22.19 * * *$

(1.158)

$9.23 * * *$

$(1.187)$
$4.96 * * *$
$49.85 * \star *$

$41.50 * * *$

$47.59 * * *$

(1.217)

0.10

(1.140)

$7.24 * \star \star$

(1.089)

$13.54 * \star *$

(1.188)

$16.08 * * *$

(1.697)

$22.31 * \star *$
$(1.488)$

16.04 ** *

(1.511)

- 0.17

(1.176)

$4.07 * \star *$

(1.084)

$7.02 * \star *$

(1.168)

10.72 ** *

(1.694)

$24.81 * \star *$

(1.414)

$20.60 * * *$

(1. 368)

3. 82 **

(1.482)

$-2.66$

(1.680)

3. 62 *

(1.508)

$7.15 * \star *$

(1.414)

$13.09 * *$ *

(1.522)

$18.24 * * *$

(2.239)

$22.34 * \star *$

(1.961)

$15.83 * \star *$

(1.978)

$-3.75 *$

(1.576)

4.57 *

(1.403)

$7.21 * * *$

(1.527)

11.65 ** *

(2.224)

$25.60 * *$ *

(1.854)

$19.65 * * *$

(1.806)

$-2.95$

(1.985)

$-6.54 * \star *$

(1. 452$)$

(1.953)

$-42.34 * * *$

1.343)

1.41

(1.282)

$6.65 * * *$

(1.257)

$13.67 * * *$

(1. 446 )

$13.96 * * *$

$(1.984)$
$22.66 * *$

$22.66 * * *$
$(1.735)$

$14.99 *$ * *

(1.722)

$(1.722)$

(1.298)

1.64

(1.245)

$3.87 * \star$

(1.397)

$10.76 * *$ *

(2.009)

$21.46 * * *$

(1.639)

$17.31 * * *$

(1.563)

$12.34 * * *$

$-38.63 * * *$

(1.624)

$(1.682)$

$-2.91$

(1.650)

$-32.36 * \star *$

(1.226)

(1.380)

School Characteristics

9. 52 ** *

(1.727)

(1.339)

$5.64 * * *$

$11.45 * * *$

(1. 781)

(1.392)

$9.04 * * *$

$11.65 * * *$

(1.876)

(1.468)

$6.32 * * *$

(1.736)

2.13

(1.697)

$35.36 * * *$

(1.326)

$34.00 * * *$

(1.328)

(1.007)

24.62 ***

$23.95 * * *$

(1.221)

$13.94 * *$ *

(0.937)

(1.220)

0.927

$-0.44$

(0.978)

$7.06 * * *$

$(0.944)$

$-0.73$

(1.066)

$-0.24$

$6.64 * * *$

(1.528)

3.27 *

(1.592)

2. 30

(1.702)

$-1.53$

(1.601)

$-4.37 * \star$

(1.540)

$28.93 * * *$

(1.153)

$20.87 *$ *

(1.096)

$0.98 * *$

(1.057)

1.19

(0.840)

$7.20 *$ *

(0.727)

-0.85
$(0.813)$

$-2.53$

(1. 772)

(1.359)

$-8.71 * * *$

$-9.27 * * *$

(1.762)

$(1.350)$
$-7.81 * * *$

$-6.17 * \star *$

$10.50 * * *$

(0.821)

$-1.79$

(0.928)

-3.18 *

(1.459)

(1.476)

(1. 760)

$-7.40 * \star *$

(1.355)

7.43 ** *

(1. 468)

(1.376)

(1.799)

2.80

(1.501)

$6.83 * * *$

(1.185)

(1.360)

(1.801)

(1.481) 


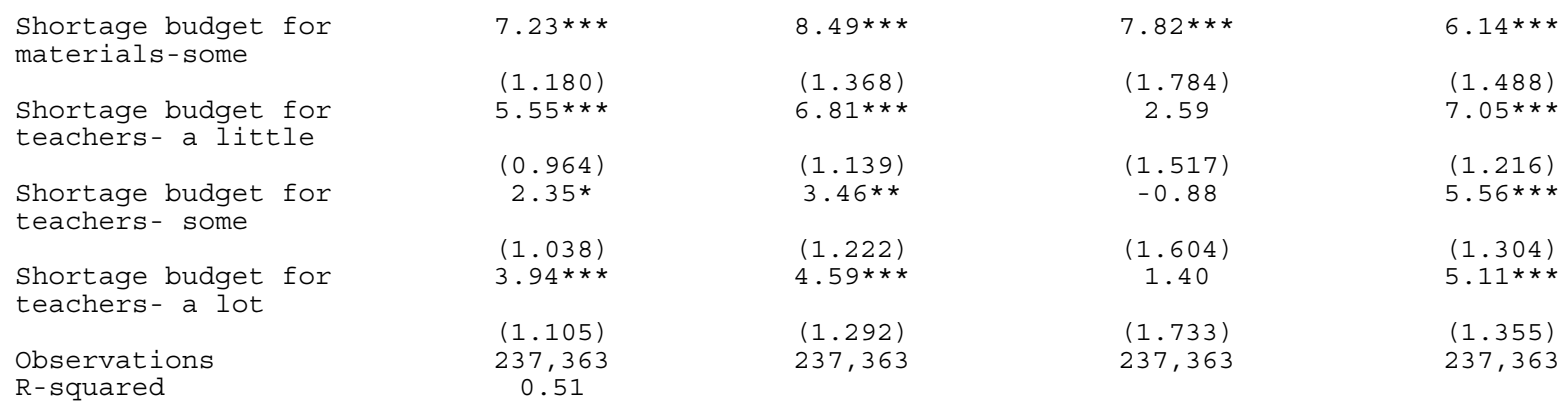

Robust standard errors in parentheses; $\star \star \star p<0.001, * \star p<0.01, *$ p $<0.05 ;$ Constant, year and country dummies included but not reported below.

Countries included: Australia, Bahrain, Armenia, Botswana, Bulgaria, Taipei, Cyprus

Palestine, Ghana, Hong Kong, Hungary, Indonesia, Iran, Israel, Italy, Japan, Jordan Korea, Lebanon, Lithuania, Malaysia, Morocco, Norway, Romania, Russia, Saudi

Singapore, Sweden, Syria, Tunisia, Egypt, USA, Serbia, England, Scotland. Omitted country for OLS regression is Cyprus \& Romania; Omitted country for quantiles are Romania \& Bahrain.

Omitted variables: n of books at home none or very few; mother/father has ISCED 1 or did not go to school; school in town with < 3000 people; Shortage

budget/material/teachers - a lot;

Table 1d TIMSS Pooled - All Countries 2003 and 2007

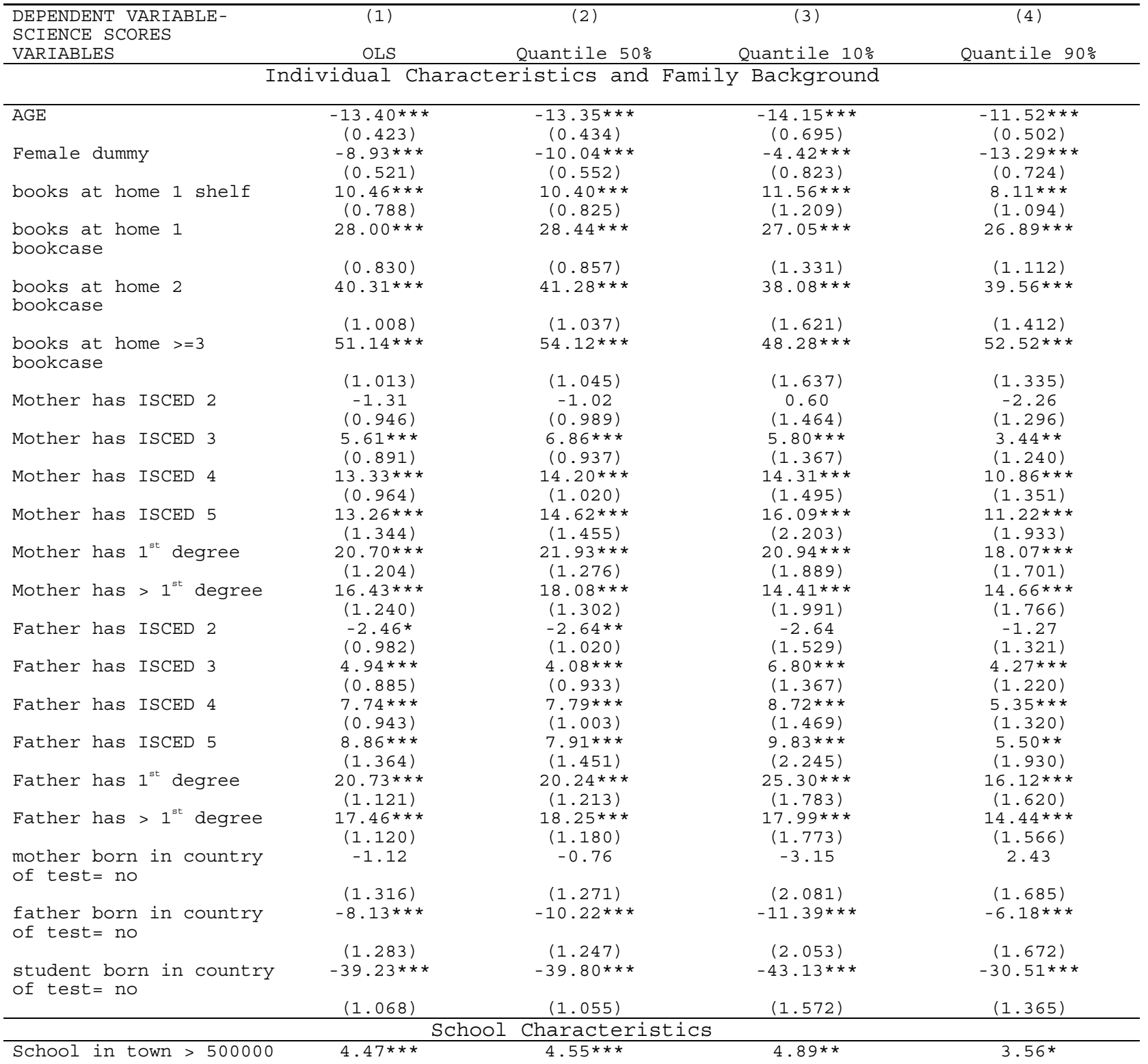




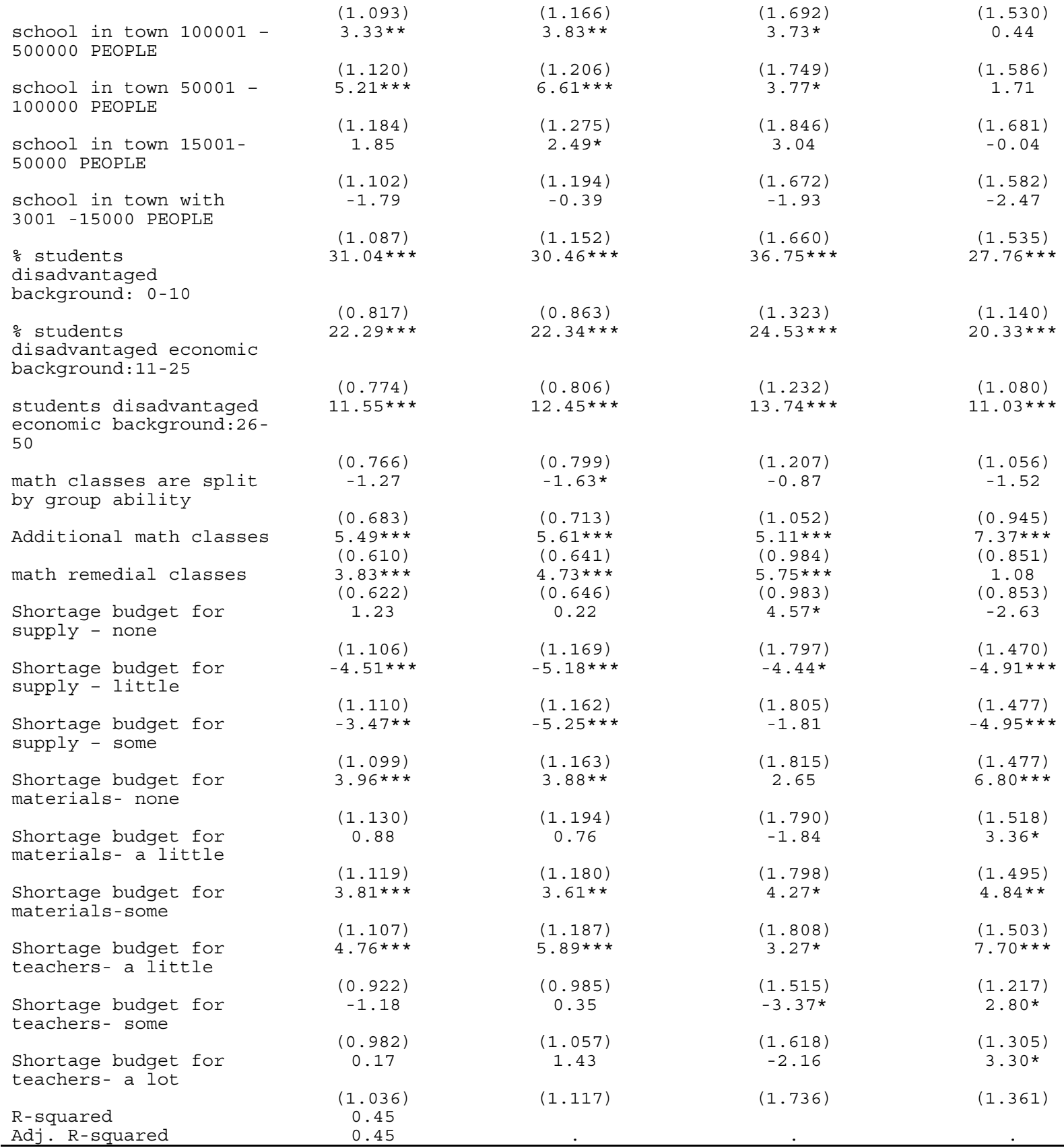

Robust standard errors in parentheses; $* \star * p<0.001, * * p<0.01, * p<0.05$; Constant, year and country dummies included but not reported below.

Countries included: Australia, Bahrain, Armenia, Botswana, Bulgaria, Taipei, Cyprus Palestine, Ghana, Hong Kong, Hungary, Indonesia, Iran, Israel, Italy, Japan, Jordan Korea, Lebanon, Lithuania, Malaysia, Morocco, Norway, Romania, Russia, Saudi Singapore, Sweden, Syria, Tunisia, Egypt, USA, Serbia, England, Scotland. omitted countries: Cyprus \& Romania. Constant Included but not reported.

Omitted variables: n of books at home none or very few; mother/father has ISCED 1 or did not go to school; school in town with < 3000 people; Shortage

budget/material/teachers - a lot;

Table 2a TIMSS Russia estimates: 1995 and 1999

\begin{tabular}{lcc}
\hline & MATH & $(2)$ \\
& MCIENCE \\
\hline VARIABLES & Quantile 50\% & Quantile 50\% \\
\hline Individual & Characteristics and Family & Background \\
\hline \multirow{2}{*}{ Student Age } & $-1.67 * *$ & $-2.42 * * *$ \\
Female Dummy & $(0.584)$ & $(0.555)$ \\
& -3.11 & $-20.11 * * *$ \\
Test language at home & $(2.643)$ & $(2.671)$ \\
& -12.23 & 7.44
\end{tabular}




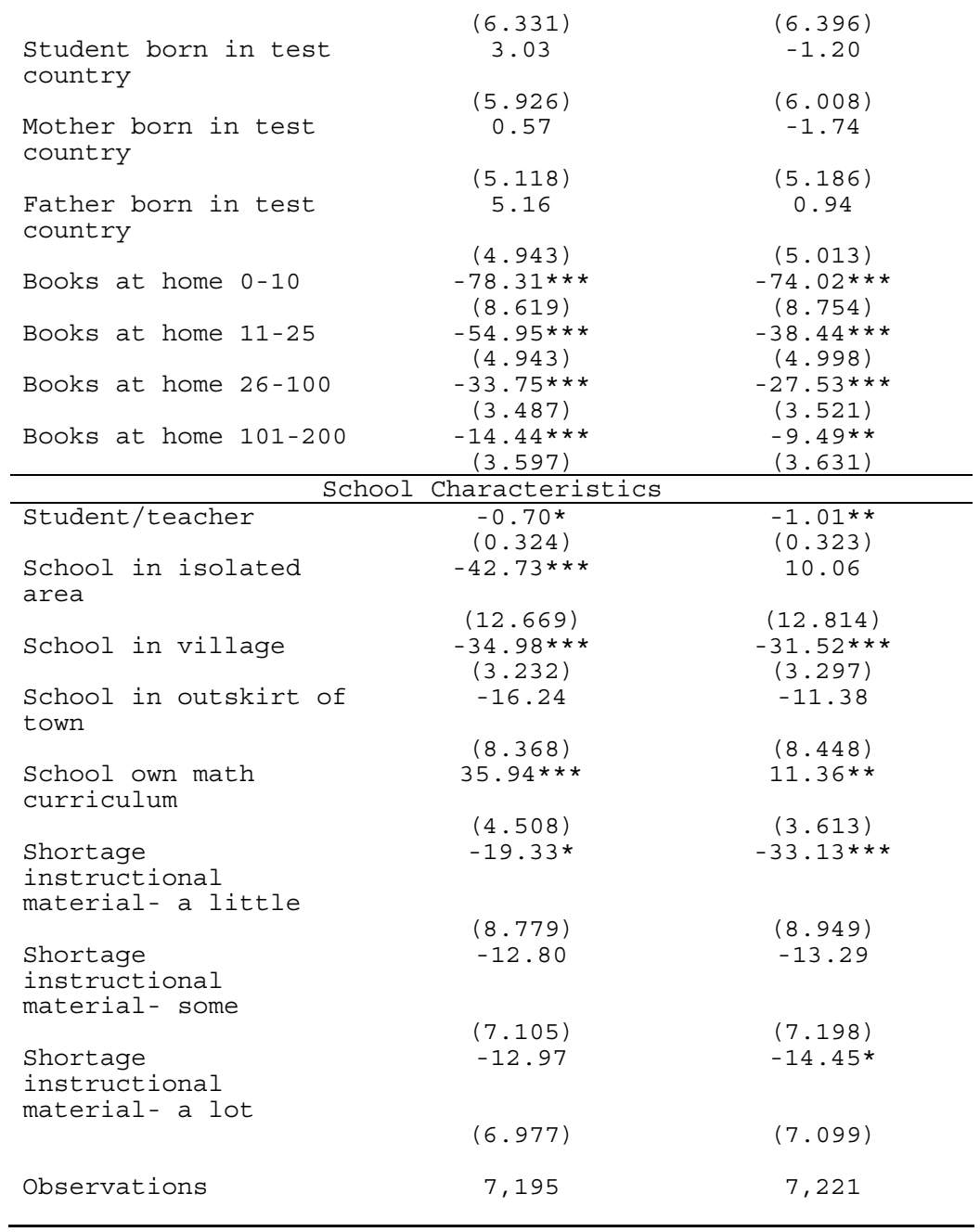

Robust standard errors in parentheses; $* * * \mathrm{p}<0.001, * * \mathrm{p}<0.01, * \mathrm{p}<0.05$; Constant and year dummies included but not reported below.

Omitted dummies: the number of books at home > 200; school location is school located close to town/city centre; Shortage instructional material none.

Table 2b TIMSS Russia estimates: 2003 and 2007

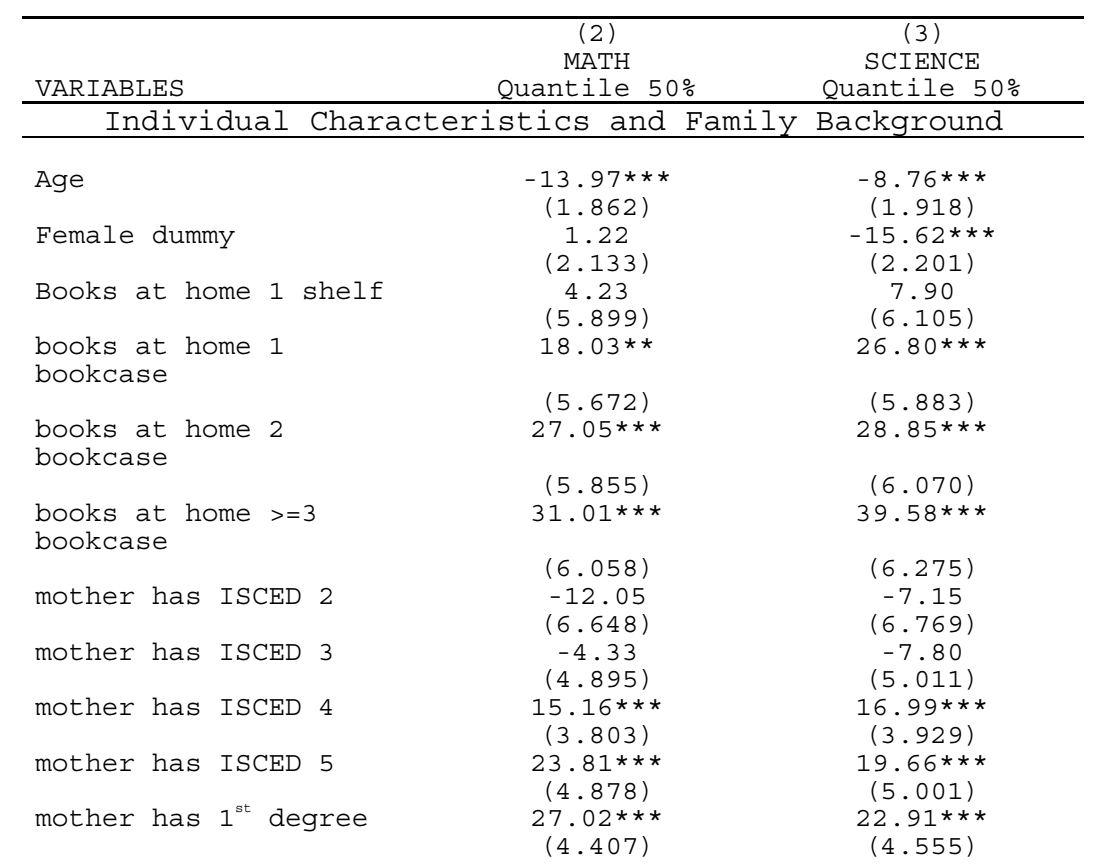




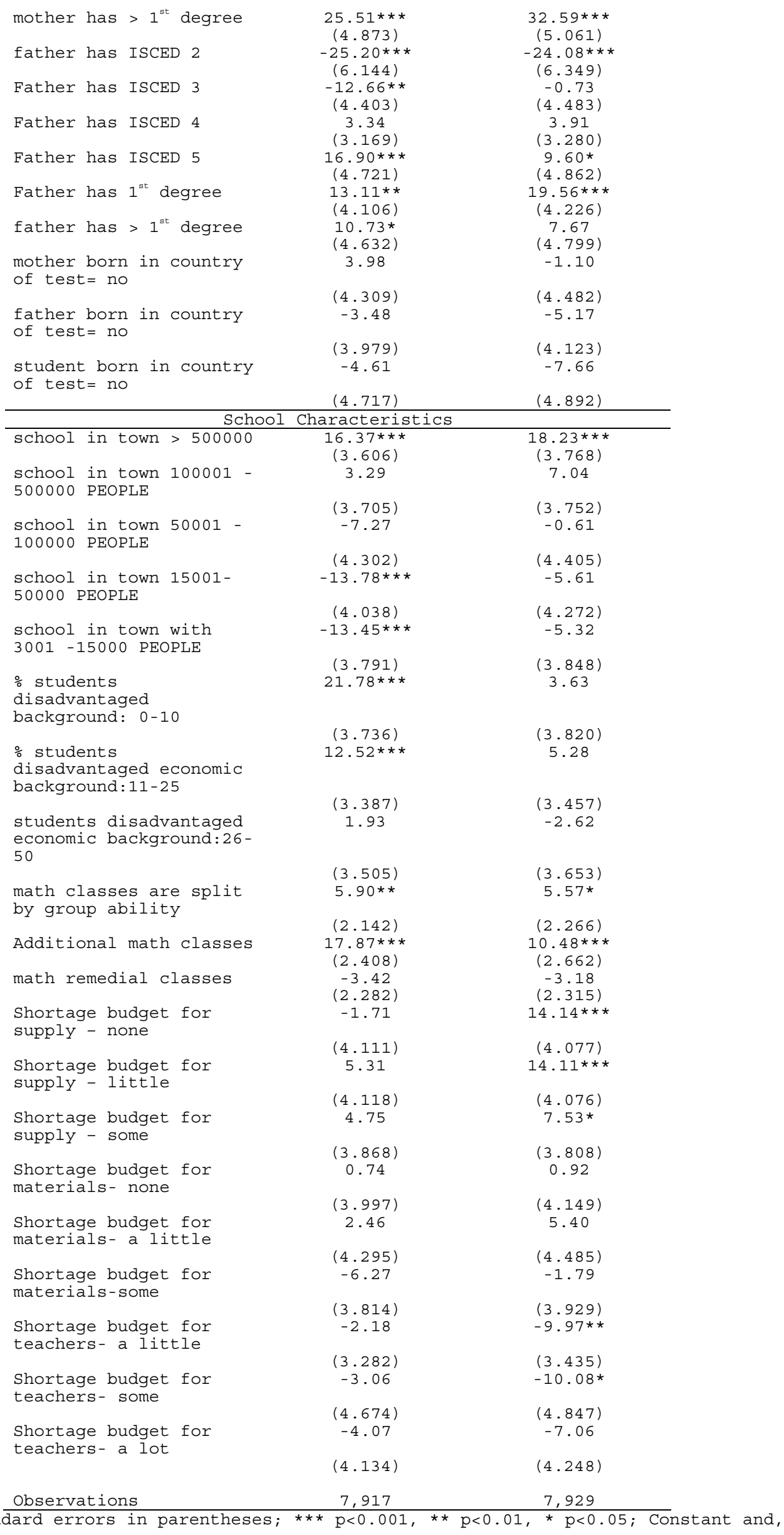


year dummies included but not reported below. Omitted variables: no of books at home= none or very few; mother/father has ISCED 1 or did not go to school; school in town with < 3000 people; Shortage budget/material/teachers=a lot 